\title{
Türk Kültüründe Egemenliğin Dinsel ve Mitolojik Kökleri
}

Şahin BAL

\section{Religious and Mythological Origins of Domination in Turkish Culture}

Citation/@): Bal, Şahin, (2017). Religious and Mythological Origins of Domination in Turkish Culture, Milel ve Nihal, 14 (1), 234-269.

Abstract: This article deals with the social factors at formation of the state and the sovereignty concepts in the history, and foundations of sovereignty at Gokturk Empire which used Turk name as a political nationality. As a result of this study a hypothesis was developed which says that every political power emerges because of a humanistic requirement, and a result of people's longings and their experiences. This power gains legitimacy with values of society which indicatives "the common good" like a religion. These values are rationalities of the society at first but with the passage of time they undergo degeneration. After this point the power begins to create some mythological stories to legitimate it's sovereignty.

Key Words: State, sovereignty, society, religion, mythology, Turks.

Okutman, Hitit Üniversitesi, İlahiyat Fakültesi, Arap Dili ve Belagati Anabilim Dalı [shahinbal09@gmail.com] 
Atıf/C): Bal, Şahin, (2017). Türk Kültüründe Egemenliğin Dinsel ve Mitolojik Kökleri, Milel ve Nihal, 14 (1), 234-269.

Öz: Bu makalede devlet ve egemenlik kavramlarının ortaya çıkmasındaki sosyolojik gerekçeler değerlendirilmiş, Türk adını siyasi olarak tarih sahnesine çıkaran Göktürk Devleti'ndeki egemenliğin dinamikleri incelenmiştir. Bu incelemeden her iktidarın toplumsal ve insani bir gereksinim sonucunda toplumun deneyimleri, özlem ve arayışlarının bir ürünü olarak toplumun din gibi ortak iyiyi temsil eden değerleri etrafında oluşup bu değerlerden meşruiyet kazandığı, bu değerlerin aşınmaya uğraması sonucunda iktidarın meşruiyetinin mitolojik unsurlara bağlayarak ayakta durma çabası gösterdiği varsayımına ulaşılmıştır.

Anahtar Kelimeler: Devlet, egemenlik, toplum, din, mitoloji, Türkler.

\section{Giriş}

İnsanın doğası gereği sosyal bir varlık olduğu kabulünün günümüzde pek çok bilimsel disiplin tarafından üretilen fikirlere kaynaklık ettiği bilinen bir gerçektir. Öyle ki yeryüzünde var olduğu günden bu yana insanlar yaşamlarını birbirleriyle değişik düzeylerde ilişkiler kurarak sürdürmüş, doğaya karşı verdikleri var oluş mücadelelerinde işbirliğine gitmişlerdir. Öte yandan insanların nüfusu arttıkça belli bir bölgedeki doğa kaynaklarını kullanma konusunda değişik organizasyonlar oluşturmuşlar ve insanlık tarihi bu organizasyonların birbiriyle olan pozitif veya negatif ilişkileri sonucunda şekillenmiştir. İnsana özgü organizasyonların ilki ve çekirdeği şüphesiz ailedir. Rousseau'ya göre bütün toplumların geçmişi aileye dayanır ${ }^{1}$.

Ailenin yapısı temelde kan bağına dayansa da çocuklar kendilerini koruması için ana babaya muhtaç oldukları sürece aileye bağlı kalırlar, bu gereksinim ortadan kalktıktan sonra ailenin doğal bağlarında bir zayıflama görülür. Çocukların ana babaya bağlılıkları ortadan kalktıktan ve ana babanın çocukları koruma sorumluluğu zorunluluk olmaktan çıktıktan sonra yani çocuklar doğayla ve sürdükleri yaşam koşullarıyla baş edebilecek düzeye eriştikten sonra aile bir birlik halinde kalmaya devam ediyorsa artık bu birliktelik doğal bir örgütlenme olmaktan çıkar ve bilinçli bir uzlaşının ürünü

${ }^{1}$ Jean Jacques Rousseau, Toplum Sözleşmesi, s.7 
durumuna gelir. Bu anlamda aile siyasi toplumların ilk örneği olarak kabul edilebilir². Evlilikler ve yeni doğanlar yoluyla aileler büyüdükçe, yeni çekirdek aileler ortaya çıkar. Bu ailelerin bağlarını bir uzlaşı içinde tutmak için yeni bir toplumsal birim gerekir ve bu birime sülale ya da klan adı verilir. Klanlar birleşip kabileyi oluşturur. Kabileler etnisite olarak isimlendirilen yapıyı belirler. Etnisiteyi oluşturan uzlaşının temelinde kan bağı (konviksiyum) ve birlikte yaşama arzusu, ya da kader ortaklığı etme gibi iki temel etken bulunur.

Tarih içerisinde bir bölgede yaşayan insanların popülasyonu arttıkça doğa kaynaklarının paylaşımında bir takım sorunların yaşanması doğal bir sonuç olmuştur. Kabileler ya da etnisiteler akrabalık bağına dayalı ilkel organizasyonlar oldukları için birbirleriyle giriştikleri kaynak kazanma mücadelesi dünyanın çoğu yerinde sosyal bir kaos oluşturmuştur. Böyle bir kaosun varlığı hayvancılık ve avcilıkla uğraşan göçebe toplumlar için de, yerleşik hayata geçerek tarımsal üretim yapan toplumlar için de geçerli olmuştur. Deyim yerindeyse rant paylaşımının ya da paylaşılamazlığının ürettiği sosyal kargaşaların sonucunda eski dünya insanları kanlı bedeller ödedikten sonra bu paylaşımda belirleyici olması için bütün kabile ve etnisitelerin uzlaşacağı hakem bir değere ya da bütün kabile ve etnisiteleri kapsayan da güçlü bir organizasyona gereksinim duymuşlardır. Bunun sonucunda günümüzde devlet adını verdiğimiz siyasal yapılar ortaya çıkmıştır. Bu bağlamda devlet denilen mekanizmanın doğuşunun sosyal bir zorunluluk olduğunu vurgulamak gerekir. Tabi, burada devleti ortaya çıaran sosyal zorunlulukla, devletler oluştuktan sonra devletlerarası mücadeleleri arasında bir ayrım yapılmalıdır.

Nietzsche devletin orijinini "sarışın, yırtıcı hayvanlardan oluşmuş bir sürünün bütün harpçi teşkilatlarıyla ve bütün teşkilatlandırma gücü ile sayıları itibariyle kendilerinden muazzam surette üstün fakat şekilsiz insanlar üzerinde dehşet saçıcı pençelerini geçiren fatihler ve efendilerden oluşan bir urk" olarak görmesi, Ratzenhofer'in devleti yaratan aracı şiddet olarak tanımlaması, Summer'in devleti gücün bir ürünü olarak kabul edip varlığını güç kullanarak

${ }^{2}$ Bkz. Rousseau, s.7 
sürdürdüğünü iddia etmesi ${ }^{3}$ gerçekte devletin ortaya çıkışı ile ilgili değil ortaya çıktıktan sonra işleyişindeki sıkıntıları dile getiren eleştirilerdir. Nitekim tarihte herhangi bir coğrafyada kurulan bir devletin kuruluş öncesi dönemi incelediğimizde o bölgede kabileler veya etnisiteler arasında büyük anlaşmazlıkların bulunduğunu, yağma, gasp, katliam gibi kanlı eylemlerin had safhaya ulaştı̆̆ını görürüz. Yakın tarihten bir örnek vermek gerekirse işgal yıllarında (1918-1922) Anadolu coğrafyasının durumunu bu realiteyi net olarak gösteren bir ortam olarak kabul edebiliriz. Otoritesini kaybetmiş bir devletin toprağında işgalci güçler bir tarafa halkın kendi içinden çıkan çetelerin, eşkıyaların ve yol kesenlerin türemesi, silahlı etnik milislerin kendinden olmayan insanlara yapmış olduğu kıyımlar bu coğrafyada yaşayan insanların belleklerinde hala canlıdır.

Kısaca ifade etmek gerekirse devlet denilen organizasyonlar insanlar arasındaki kargaşayı önlemek için doğal olarak vücut bulmuştur. Devlet yapısının ortaya çıkmasıyla birlikte egemenlik kavramlarının da üzerinde durmak gerekecektir.

\section{Devlet ve Egemenlik Kavramlarına Kısa Bir Bakış}

Devlet kavramı tarih boyunca pek çok düşünürün ve teorisyenin ilgisini çekmiş ve bu kavramın tanımlanmasına ilişkin değişik yaklaşımlar ileri sürülmüştür. Türk Dil Kurumunun sözlüğünde bu kavram hukuksal ve toplumbilimsel açıdan "Toprak bütünlüğüne bağlı olarak siyasal bakımdan örgütlenmiş millet ya da milletler topluluğunun oluşturmuş olduğu tüzel varlık" olarak tanımlanmaktadır${ }^{4}$. Bu tanım başta olmak üzere günümüzde devlete yüklenen anlamlar incelendiğinde genel olarak günümüzdeki çağdaş devlet anlayışını yansıttığı görülür. Kimilerine göre devlet egemen sınıfın siyasal örgütüdür. Devletin amacı yürürlükteki düzenin korunması egemen sınıf tarafından diğer sınıfların baskı altında tutulmasıdır ${ }^{5}$. Timurluoğlu'na göre bu örgüt toplumun sınıflaşmasıyla birlikte sömürülen toplum katmanlarının baskı altında tutulması

\footnotetext{
${ }^{3}$ Will Durant, Medeniyetin Temelleri, s.54

${ }^{4}$ Bkz. http://tdk.gov.tr/index.php?op-

tion $=$ com_gts\&arama $=$ gts\&guid=TDK.GTS .

59347ba759b413.38355903. Erişim Tarihi: 04.06.2017

${ }^{5}$ Vecihi Timurluoğlu, "Mitolojide Devlet Bilgisi" Memleket Siyaset Yönetim Dergisi, sayı:1, 2006. s.1
} 
için egemen sömürücü sınıfların bir aracı olarak ortaya çıkmıştır6. Diğer yandan devlet kuramları arasında devletin temellerini ailede ve onun genişlemesinde, güç ve mücadelede bulan ya da biyolojik ve ekonomik esaslara bağlayan, toplumsal sözleşmeye dayandıran farklı görüssler de bulunmaktadır ${ }^{7}$. Platon'a göre göre devletin oluşumundaki temel etken insanların kendi ihtiyaçlarını karşılayabilmek için başkalarıyla kurduğu ilişkidir. Yani toplumların ve devletin oluşumundaki faktör işbölümüdür8. Platon'un işaret ettiği noktadan bakıldığında devlet sırf kurumsallaşmış yapısıyla üzerinde değerlendirmelerin yapılamayacağ toplumu ve insanları da kapsayan gelişmiş bir organizasyondur. Nitekim görünürde siyasal bir örgütlenme olan kendini oluşturan toplumla ve bu toplumun kolektif kültürüyle sıkı sıkıya bağlıdır. Söz konusu toplumun yapısı bütün özellikleriyle kavranmadan kurmuş olduğu devletin çözümlemesini yapmak neredeyse olanaksızdır. Şimşek'in Dönmezer'den aktardığına göre devlet topluma adeta yapışmış bir teşkilatlanmadir'.

Öte yandan devlet denilen organizasyonun doğasını net olarak kavrayabilmek için doğanın bir parçası olan insanın tarihsel yaşantı ve deneyimleriyle beraber geçirdiği zihinsel ve medeni evrimin farkında olmak gerekir. Bunun anlamı insanlık medeni ve teknolojik açıdan değiştikçe devlet kavramına yüklediği anlam da değişiklik geçirmiştir. Ayrıca devletin toplumla yapışık olan doğası gereği devletlerin toplumların şekillenmesiyle birlikte örgütlendiği tarih içerisinde net olarak gözlemlenebilen bir durumdur. Bu yüzden devletlerin oluşumunu toplumların oluşumunun bir sonucu olarak görmek yanlış olmasa gerekir. Yani siyasi bir organizasyon olarak devlet toplumların biçimlenmesi neticesinde bir ihtiyaç olarak doğal bir süreçte doğmuştur. Hobbes devletin doğuşunu insanların doğal yaşamıyla toplum halinde yaşama arzuların çelişmesine bağ-

\footnotetext{
${ }^{6}$ Timurluoğlu, "Mitolojide Devlet Bilgisi", s. 1.

7 Özlem Bağdatll, Kutadgu Bilig'te Devlet ve Adalet İlişkisi, s. 2.

8 Osman Şimşek, "Devlet Kavramının Gelişimi ve Küreselleşmedeki Anlamı" Devlet Kavramının Gelişimi ve Küreselleşmedeki Anlamı" Kaynak Site: http://www.kamu-is.org.tr/pdf/5413.pdf. Erişim Tarihi: 04.06.2017.

9 Şimşek, Devlet Kavramının Gelişimi ve Küreselleşmedeki Anlamı”, s. 1.
} 
lar. Onun teorisine göre insanların hareketlerini sınırlayan ve denetleyen üst bir otorite olmaksızın insanlar sürekli olarak birbirleriyle çatışma halinde olacaklardır. Bu çatışmanın nedeni insanlardaki özgür olmak güdüsü ya da doğal kaynaklardan daha fazla pay alma tutkusu olabilir. Çünkü özgür olma, daha iyi koşullarda yaşama, birbiriyle rekabet etme, güvende olmaya dönük kuşku gibi dürtüler Hobbes'e göre insanın tabiatında fazlasıyla mevcuttur ${ }^{10}$. İnsana özgü bu tutkular yüzünden her toplumda çatışmalar yaşanır ve bu çatışmaların bedelini insanlar tarih boyunca sıklıkla canlarıyla ödemişlerdir. Zira tutkuların savaşımında sonuç olarak ortaya ancak kan çıkar, tutkuların elinde tutsak olan insanlar tarih boyunca birbirlerine hayvanlarda dahi görülmeyen bir iştahla saldırmıştır ${ }^{11}$. Bu çatışmaların bitirilmesi, en azından minimum düzeye indirilmesi için üst bir otoriteye gereksinim duyulmuştur ve bu otorite de devlettir. Bu bağlamda Yuvalı'ya göre devlet insan zekâsının bulduğu medeniyetin gelişmesine en çok yardım etmiş olan siyasi organizasyondur ve devletlerin kurulması insanlığa yapılan en büyük hizmet olmuştur ${ }^{12}$.Bu bağlamda çağımızda bazı devletlerin egemen sınıfın gücünü temsil eden siyasi aygıt olarak tanımlanmasını devlet örgütünün tarihsel gelişimini göz önünde bulundurmadan yapılan bir genelleme olarak kabul etmek gerekir. Bu değerlendirmeler ışığında devlet insanların barış ve güvenlik içerisinde kolektif bir yaşam sürmek uğruna bazı özgürlüklerinden feragat edip, ortak bir hukuk arayışı neticesinde ortaya çıkan bir kurum olarak görülebilir. Ortak bir hukuk arayışı ve güvenli bir yaşam isteğinden söz edince devlet kurumu ile birlikte adalet dediğimiz soyut kavram da ortaya çıkacaktır. Gerçekte herkesin kabullendiği bir üst otorite olan devletin varoluş gerekçesini eski dünyada da modern çağda da adaleti sağlamak olarak görmek gerekir. Devletlerle birlikte yazılı ya da yazısız yasaların da ortaya çıktığını devletler tarihini incelediğimizde görürüz. Devleti oluşturan temel değer bu anlamda adalettir. Her devlet kuruluşu itibariyle herkesin üzerinde ittifak ettiği bir hakem değer ve ideoloji üzerine kurulmuştur. Roma'da hukukun oluşması, Hammurabi Yasaları, Türk devletlerindeki töre anlayışı insanlar arasında adaleti sağlama düşüncesinin eski dünyada görünen

\footnotetext{
10 Şimşek, "Devlet Kavramının Gelişimi ve Küreselleşmedeki Anlamı", s.3

${ }^{11}$ Şahin Bal, Aykırı Sesler Teolojik ve Yarn Politik Denemeler, 2017, s.103

${ }^{12}$ Abdülkadir Yuvalı, "Türk Devlet Felsefesi” Sakarya Üniversitesi Fen Edebiyat

Fakültesi Dergisi, sayl:1, 2008, s.127
} 
örnekleridir. Adalet konusunda pek çok tanım yapılmasına karşın bu konudaki kanaatimiz insanlar için davranışsal anlamda iyilik ve kötülük kavramlarının nesnel olarak tanımlanması ve işletilmesidir. Yani devlet oluştuktan sonra devleti yönetenlerin halkça benimsenen yasaları ayrım gözetmeksizin herkese eşit olarak işletmesidir. Bu bağlamda bir devletin bir yasası ya da uygulaması temelde yanliş dahi olsa devleti oluşturan toplumun her bireyine eşit işletildiği sürece devlet devlet olma yani kendini oluşturan sosyal kültürün en üst kurumu olma özelliğini taşımayı sürdürür. Yasalar ve kurallar kişilerin toplumsal statülerine göre farklı yorumlanıp uygulanırsa devlet devlet olma vasfını yitirir, Timuroğlu'nun deyimiyle egemen sınıfın güç kullanma aracına döner. Zira bir toplumda iyiliğin ve kötülüğün nesnel değil de göreceli olarak tanımlanmaya başlaması toplumu devletin kuruluşundan önceki kaos ortamına geri döndürür. İnsanlık tarihinde toplumun bireyleri arasında eşitliği gözetmeyip eşitsizliği ve ayrıcalıklı hukuku işletmeye başlayan bütün devletlerin çöküş sürecine girdiği sosyologlar tarafından kabul edilen bir gerçekliktir. Kısacası diyebiliriz ki tarihte kurulan bütün devletler sosyolojik bir gerekçe ile kendi dönemi içerisinde rasyonel bir aklın ürünü olarak ve kaosa karşı düzen ve adalet arayışı neticesinde ortaya çıkmıştır.

Devlet hakkında konuşunca devleti oluşturan unsurlar üzerinde de durmak gerekir. Çağdaş araştırmacılar devletin oluşması için millet, ülke, egemenlik ve siyasal örgütlenme gibi dört temel dinamikten bahsetmektedirler ${ }^{13}$. Bir devletin oluşabilmesi için doğal olarak bir insan topluluğuna, belirli sınırları olan bir toprak parçasına ve siyasal bir örgütlenmeye gereksinim vardır. Makalenin odak konularından biri egemenlik olduğu için diğer unsurlar üzerinde ayrıntılı bir çözümleme yapılmayacaktır.

Devletler uzunca süre egemen birimler olarak insanlar arasındaki hukukun tek belirleyicisi ve uygulayıcısı olmuşlardır. Bu bağlamda egemenliği temel anlamda devletin insanlar üzerinde hükmetme yetkisini meşrulaştıran bir araç olarak görmek gerekir ${ }^{14}$. Egemenlik devletle özdeşleşen ve devletin ayırıcı vasfı olarak görü-

\footnotetext{
${ }^{13}$ Bağdatlı, Kutadgu Bilig'te Devlet ve Adalet İlişkisi, s.2

${ }^{14}$ Beriş, Emrah H, “Egemenlik Kavramının Tarihsel Gelişimi Üzerine Bir Değerlendirme" Ankara Üniversitesi SBF Dergisi, cilt.63, sayı:1, 2008, s.55
} 
len bir kamusal güçtür. Bu gücün devlete getirdiği toplumsal ve siyasal alanı düzenleme amaciyla norm koyma ve bunların gereklerini yerine getirme yetkisidir. Egemenlik kavramını ilk olarak Fransız hukukçu Jean Bodin ortaya atmıştır. Bodin'in tanımlamasına göre egemenlik kavramını devletin mutlak ve sürekli gücünü nitelemek için kullanmıştır. Bodin'e göre egemenlik mutlaktır; güç, işlev ya da süre açısından sınırlandırılmamıştır ${ }^{15}$. Egemenliğin doğuşu devlet organizasyonun şekillenmesiyle eş zamanlıdır, devleti oluşturan halkı bağlayıcı bir niteliktedir. Fransız Devrimi sonrasında ulusal egemenlik kavramı ortaya çıkıncaya dek Tanrıdan sonra üzerinde hiçbir güç tanımayan bir özelliğe sahiptir. Ülkeyi yönetme, ülkede yaşayan insanlar üzerinde tasarrufta bulunma yetkisi olarak özetlenebilecek olan egemenlik kavramını Thomas Hobbes tarafından güvenlik endişesinden hareketle rasyonel bir zemine oturtulmuş devletle birlikte Tanrısal yasalar ile bağlantısı kesilmiştir. Böylece siyasal iktidarı ve egemenliği meşrulaştırmak için teolojik destek arayışı bitmiştir ${ }^{16}$.

Beriş'in aktarımlarından anlaşıldığına göre Avrupa'da aydınlanma dönemine kadar dünya devletlerinin egemenlik anlayışı ve siyasal iktidarın meşruluk sorunu teolojik öğretilerle sağlanmıştır. Mezopotamya'da ortaya çıkan Tanrı Devletler, Mısır'da Tanrının yeryüzündeki gözü anlamına gelen Firavun sözcügünün hükümdarların sıfatı olarak kullanılması, Ortaçağ Avrupası'nda kralların Papa'dan berat alması, Eski Türk hükümdarlarının Tanrıkut (Tanrının yönetme yetkisini verdiği kişi) sıfatıyla ülkeyi idare etmeleri eski dünyada egemenliğin ve siyasal iktidar anlayışının teolojik temelde olduğunun göstergesidir. Öte yandan devlet kavramıla birlikte ortaya çıkan egemenliğin teolojik kökleri bize başka bir fikir daha vermektedir ki bu da eski dünya devletlerinin kurulmasında ve işlemesinde inancın büyük bir rolü olduğudur. Ayrıca devletle birlikte halkların biçimlenmesinde de inancın etkisi büyüktür.

\footnotetext{
${ }^{15}$ Beriş, "Egemenlik Kavramının Tarihsel Gelişimi Üzerine Bir Değerlendirme", s. $56-57$

${ }^{16}$ Beriş, "Egemenlik Kavramının Tarihsel Gelişimi Üzerine Bir Değerlendirme", s.58
} 


\section{Mitoloji ve Egemenlikle İlişsisi}

Bilindiği üzere mitoloji mitosları inceleyen bilim dalıdır. Mitos kavramı Türkçede efsane ya da söylence sözcükleriyle karşılanmaktadır. Kavram olarak Türkçe Sözlükte "Tarih öncesi tanrıların yaşamlarını, kahramanların serüvenlerini anlatan, bir toplumun inançlarını ve eğilimlerini anlatan efsaneler olarak" tanımlanmıştır $^{17}$. Fakat burada destanlar ve masallar ile mitoslar arasında bir ayrım yapmak gerekir. Mitosların kahramanları tanrı ya da tanrılar, ruhlar ve doğaüstü güçlerdir. Destanların ve masalların kahramanları ise sıradan insanlardır ${ }^{18}$. Kahramanları tanrılar olması itibariyle mitosların temelinde teolojik bir durumun olduğunu kabul etmek gerekir. Fakat aralarındaki ortak nokta mitosların, masal ve efsanelerin sözlü kültür ürünü olduklarıdır. Bu noktada antropologlar arasında bir uzlaşı söz konusudur ${ }^{19}$. Mitoslar, destanlar ya da masalların ne zaman üretildiklerini tespit etmek olanaksızdır. Fakat sözlü kültürün ürünü oldukları için kuşaktan kuşağa aktarılırken oldukça fazla süslemeye, abartıya uğradıktan sonra yazıya geçirilmiş hallerini aldıklarını söylemek mümkündür. Bu anlamda söz konusu anlatılar zaman içerisinde büyük bir semantik değişime uğramışlardır. Eski dünyanın söylenceleri her ne kadar çağdaş düşünce tarafından eleştirilere maruz kalıyorsa da mitosların, masal ve destanların toplumsal bilinç ve kimliğin oluşmasına tarihi içerisinde büyük katkı sağladıkları söylenebilir.

Mitosları tanımlarken özellikle inançla ilgili olduklarından bir dönem bir halk tarafından üzerinde uzlaşılan birleştirici kutsal bir değerin zaman içerisinde sözlü aktarıma dayalı olarak farklılaştığını söylemek gerekir. Zira Yunan, Mezopotamya, Arap, Hint ve Orta Asya mitolojilerine baktığımızda çok tanrılı ve çok kutsallı inanç sistemlerinin tamamında bütün tanrıların üzerinde en saygın ve en güçlü pozisyonda bir baş tanrının bulunduğu görülecektir.

Bir halkın üzerinde uzlaştığı ve kendi aralarındaki ilişkilerde hakem tayin ettiği ahlaki otorite olan tanrı ve bu tanrının nitelikleri

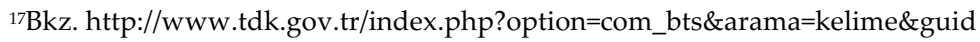
$=$ TDK.GTS.5935d6b7ba8d74.94495663

${ }^{18}$ Zeliha Etöz, "Mitos ve İktidar" Ankara Üniversitesi SBF Dergisi, cilt:66, sayı:3, 2011. s.165.

${ }^{19}$ Etöz, Mitos ve İktidar", s. 165.
} 
konusundaki anlatılar kültürün sözlü olarak aktarımı aşamasında ve bu süreçte geçen yüzyıllar boyunca büyük bir dejenerasyona uğradığı varsayılabilir. Ayrıca insanların muhayyileleri ya da yaşam deneyimlerinin bir ürünü olarak baş kutsala bağlı olarak başka kutsallar üretmeleri ve baş kutsala tanıdıkları saygınlığı yeni üretilen kutsallara da vermeleri temelde tekil bir karakter taşıyan tanrı fikrinin çoğul forma ulaşmasına ve bir panteon oluşmasına neden olduğu düşünülebilir. Zira insanları var eden bir Tanrı fikri kurumsallaşmış herhangi bir dinin dayatmasıyla öğrendikleri bir kabul değil insanların kendisi, doğa ve evren üzerinde gerçekleştirdiği düşünme etkinliğinden hâsıl olan mantıklı bir sonuçtur ${ }^{20}$. Bu bağlamda var olan hakem değer tanrı fikrinin insanların yaşantılarını inanç haline getirmesi sonucunda başkalaşım geçirdiğini söylemek gerekir.

Ali Şeriati mitolojiyi özel bir bilim olarak tanımlar. Bu alanda araştırma yapmak için insanın zihinsel bir deneyime sahip olması gerektiğini belirtir. Ona göre mitosların sembolleri aşılarak altında yatan temel gerçeğe ulaşmak gerekir. Efsaneler bütün dinlerin ve kültürlerin tanınması için birer anahtardır. Mitoslar sosyal bir devrenin bitiş ve çöküşünü gösteren birer aynadır ${ }^{21}$. Mitosların konusu tanrılar, ruhlar ve doğaüstü güçler olduğu için bu anlatıların profan olduğu yani toplumsal kutsallar ve dinle bağlantısız oldukları düşünülemez. Gündüz'e göre insanın kutsal ya da kutsiyetle ilgili değerlendirmelerini ve kutsal alan olarak kabul ettiği değerleri ve değer yargılarıyla olan ilişkisini dikkate almadan insan davranışlarını anlamak neredeyse olanaksızdir ${ }^{22}$. Ayrıca mitoslar insanların içinde yaşadığı sosyal çevreye, yaşamına yön veren paradigmalara, kendisini bağlı hissettiği değerlere ve sahip olduğu ideolojilere dayalı olarak bir takım kutsal alanlar oluşturur ve zamanla bu kutsallara dönük anlatılar olarak ortaya çıkar. Kutsala ilişkin anlatıları ifade eden mitoslar zamanla değişebilen ve kültürden kültüre geçişken olan yapılarıyla her yerde varlıklarını sürdürebilmektedir. İnsanlar bu anlatılar yoluyla kendilerini ve içinde yaşadıkları evreni

\footnotetext{
${ }^{20}$ Şahin Bal, Sorgulanmadan Sorgulamak Teoloji Yazıları, 2015, s. 14.

${ }^{21}$ Ali Şeriati, Medeniyet Tarihi I, s. 113.

22 Şinasi Gündüz, "Kutsal Hakkında Konuşmak: Dinsel Söylemde Mitos” Milel ve Nihal Dergisi, cilt:6, sayı:1, 2009, s. 10.
} 
tanımaya, tanımlamaya, geçmişe ve geleceğe dönük bilinmeyeni algılamaya ve metafizik âlemle irtibat kurmaya çalışmaktadır ${ }^{23}$.

Mitosların kutsallık ve tanrısallıkla olan ilişkisi Ali Şeriati'yi efsaneleri mitosların karşısında konumlandırmaya götürmüştür. Ona göre efsaneler Allah'ın yarattığı dünyaya karşı insanların yarattığ1 dünyadır. Tarihin aksine zıttı olarak üretilen gerçeklerdir fakat hakikat değillerdir ${ }^{24}$. Ali Şeriati'nin bu düşüncesinde mitosların kahramanlarının tanrılar olduğu için efsanelerin kahramanlarını insanlar olarak gördüğü sonucuna varılabilir. Nitekim burada efsaneyi destan anlamında kullandığı açıktır.

Mitoslar konusunda araştırmacının görüşü önceki paragraflarda belirttiği üzere bunların insanların siyasal ve sosyal yaşantıları gereği bir zamanlar insanların üzerinde uzlaştıkları teolojik bir ortak paydanın zamanla yozlaşmış biçimleri oldukları yönündedir. Her ne kadar metafizik unsurlara dayalı anlatılar olsalar da insanların bu metafizik unsurları fiziksel dünyadaki yaşantılarının bir sonucu olarak ürettiklerini söyleyebiliriz.

Mitosların devlet ve egemenlik konularıyla ilişkisine gelince bu konuda öncelikle bir kültürdeki mitosların ya da efsanelerin devleti ve devletle birlikte ortaya çıan egemenliğin oluşmasında ciddi bir katkılarının olmadığını söylemek gerekir. Çünkü devletlerin kuruluşlarını incelediğimizde ilk devletlerden çağdaş sayılabilecek organizasyonlara dek hepsinin temelinde toplumsal bir uzlaşmanın var olduğu göze çarpar. Örneğin Medine'de kurulan İslam devletinin kuruluşundaki Medine Vesikası örneği bir devletin kuruluşuna dair gerçekleşen sosyal uzlaşının yazılı olarak elimizde olan bir belgesidir. Yazılı kültürün olmadığı toplumlarda ise devletin meşruiyeti devleti oluşturan kabile ve etnisite gibi birimlerin bir konsorsiyumu biçiminde gerçekleşmiştir. Bu daha çok çok uluslu ve çok kültürlü devletlerin yapısı gibi gözükse de başka sosyal birimler tarafından desteklenmeyen bir kabilenin, bir klanın ya da bir etnisitenin dünyada tek başına bir devlet oluşturduğu site devletleri d1şında az rastlanan bir durumdur. Hatta site devletlerinin yapısını

\footnotetext{
${ }^{23}$ Gündüz, "Kutsal Hakkında Konuşmak”, s. 25.

${ }^{24}$ Şeriati, Medeniyet Tarihi I, s.116
} 
incelediğimizde bile bünyesinde değişik etnik unsurları barındırdığ görülecektir.

Çağdaş devletlerde iktidara gelme gibi bir işleyiş olduğundan iktidara talip olan siyasi organizasyonların toplumdaki yerleşik mitosları ve inançları propagandalarına malzeme yapmaları başka bir şey devletin oluşumu esnasında toplumsal uzlaşının sağlanması başka bir şeydir. Egemenliğin meşruiyetini ve devamını sağlama amacı güden mitosların devletin oluşumunda da var olduğunu düşünmek büyük bir yanılgı olur. Çünkü egemenin ya da egemen sınıfın kullandığı mitoslar halk kitlelerinin itaatini sağlamak ya da çağdaş dönemde bir seçim esnasında tercihlerini cezbetmek için kullanılan birer araçtır. Bu bağlamda mitosları devlet kurulurken değil devlet kurulduktan sonra işleyişi kötü olsa bile kitlelerin itaatini sağlamak için üretilen söylenceler olarak kabul etmek gerekir. Örneğin kadim Yunan mitolojisini incelediğimizde baş tanrı olarak kabul edilen Zeus'un insanların kaderiyle oyuncak gibi oynayan, dilediğine dilediği gücü veren, dilediğini tanrılık konumuna çıaran, dilediğine tanrısal güçler veren kısacası evreni idare etmede adalet ilkesini hiç gözetmeyen bir kimlikte olduğunu görürüz. Gerçekte Zeus kimliği Yunanlıların bilinmeyen tarihindeki bir kral olduğu açıkça belirgindir. Diğer krallıklarla etik olmayan anlaşmalar yapan, onları birbirleriyle savaştıran, kimi zaman bir kralı kimi zaman ötekini gücüyle destekleyen, hatta bu kralların eşleriyle gayr-1 meşru ilişkiler kuran ve çocuklar edinen bir kraldır. Bu kralın gücüne bağlı olarak oluşturduğu dünya büyük olasılıkla dönemin din adamları ya da demagoglarınca inanç, hatta din haline getirilmiş ve metafiziğe inanan halka bu düzen ister istemez kabul ettirilmiştir. Timurluoğlu bu gerçeği "egemen sınıfların ilk ortakları tanrılar olmuştur" diyerek dile getirir ${ }^{25}$.

Diğer bir yandan halkların ya da ulusların şekillenişlerini devletlerden bağımsız düşünmek yanlıştır. Değişik halk kitlelerinin ortak bir otorite çevresinde birleşmesiyle oluşan devletler varlıklarını uzun süre sürdürebilmeleri için bünyesinde barındırdığ 1 halklar arasında inançsal bir ortaklık oluşturmak zorundadır. Bu inanç ortaklığı olduğu sürece devlet ihtiyacı olan ekonomik ve askeri gücü

25 Timurluoğlu, "Mitolojide Devlet Bilgisi”, s. 1. 
kolaylıkla toplayabilir, böylelikle hem egemenin otoritesini tehlikeye atacak nitelikteki iç tehditleri bertaraf edebilir hem de diş tehditlere karşı direncini arttırabilir. Yani her devlet varlığını sürdürebilmek için kendine özgü bir halk oluşturmak zorundadır. Gumilev bu halk için etnos kavramını kullanır. Etnos bir nevi etnisiteler birliği demektir. Etnik özelliklerini korumakla birlikte bir araya gelen kendisini diğer toplumlardan farklı gören, tarihin akış1 içerisinde regüler değişiklikler geçiren ve şahsına münhasır davranış kalıpları olan insan topluluğudur ${ }^{26}$. Devletin oluştuktan sonra egemenliğini devam ettirebilmesi için bu etnosu oluşturması gerekir, ya da egemenin stratejileri sonucu bu etnos kendiliğinden oluşur. Gumilev'in şahsına münhasır davranış kalıpları ifadesi insanların ortak inanç, ortak ülkü ve ortak etik değerler etrafında birleşmesiyle ortaya çıkar. Bu bağlamda toplumların ya da bir toplumun ortak hafızasında etki bırakmış tarihsel bir olayın mitosa dönüştürülerek insanlara coşkulu bir üslupla aktarılması söz konusu olabilir. Özellikle ortak köken ve ortak atadan türeyiş mitosları, ya da ortak bir tarihi kahramanın mirasçısı olma destanları ortak davranış kalıplarının oluşmasında etkilidir. Örneğin Hun imparatoru Mete'nin toplamış olduğu 24 tümenlik askeri birliğin zamanla 24 Oğuz boyuna, Mete'nin Oğuz Kağan'a dönüştürülmesi Orta Asya steplerinde Kağanlık kuran kişilerin bir şekilde soylarını Oğuz Kağan'a dayandırarak devletlerini ve egemenliklerini meşrulaştırmaları Türk tarihçilerinin kabul ettiği bir gerçektir.

Özetle bu konuda her devletin ve egemenin sosyolojik bir gereksinim ve gerekçeyle oluştuğunu bu süreçte bir toplumsal uzlaşının var olduğunu söyleyebiliriz. Mitoslar ise devlet kurulduktan sonra halk kitleleri arasında ortak duyguyu sürdürüp egemenliği bu minvalde devam ettirmek amaciyla ve devlete özgü çekirdek bir etnos ya da kimlik oluşturmak amacıyla kullanıldığını söylemek mümkündür.

\section{Türk Mitolojisinin Temel Unsurları}

Türk mitolojisi ile ilgili temel unsurların ayrıntısına girmeden önce Türk adının doğuşu ile ilgili bir takım değerlendirmeler yapmada yarar görüyoruz. Zira yaygın anlayışa göre tarih boyunca pek çok hanedan yetiştirip, pek çok güçlü devlet kuran Türkler tarafından

${ }^{26}$ L. N. Gumilev, Etnogenez Halkların Şekillenişi, Yükseliş ve Düşüşleri, s. 179 
bu isim resmi olarak iki devlet tarafından kullanılmıştır. Bu devletlerden biri bugün bizim Göktürk Devleti olarak isimlendirdiğimiz Orta Asya'da kurulan Büyük Türk Kağanlığı, diğeri ise Türkiye Cumhuriyeti'dir27. Bir de buna Kuzey Kıbrıs Türk Cumhuriyetini ekleyebiliriz. Etnik bir unsur olarak bu adı yalnızca Türgişler ve Türkmenler kullanmıştır. Romantik milliyetçi yaklaşımlarda Türk sözcüğünün anlamı her ne kadar "güçlü, kuvvetli" ya da "türeyen" biçiminde kabuller görse de Türk adının gerçek anlamını saptamak için resmi olarak kullanıldığı devleti oluşturan sosyolojik yapıya müracaat etmek gerekir.

Taneri'nin aktardığı bilgiye göre Orta Asya'da Büyük Hun Devleti'nin dağılmasından sonra tabiri caizse tam anlamında karanlık bir çağ başlamıştı ${ }^{28}$. Hun devletinin yıkılışından sonra büyük bozkırda oluşan otorite boşluğu nedeniyle zaman Hun devletinden geri kalan etnik bakiyeler olan boyların birbirleriyle mücadelesiyle geçiyor, bu ortamda baskın, yağma, saldırı, gasp, soygun ve kitle katliamları gibi eylemler zirve yapıyordu.

$\mathrm{Bu}$ ortamın bozkırın kabileleri arasında bir güvenli bir yer arayışıyla bir takım göç hareketleri oluşturduğu düşünülmektedir. Bu göç hareketlerinin temel adresi Hun devletine de başkentlik yapmış olan günümüzde Moğolistan'ın Zavhan ve Aymak bölgesi sınırları içerisinde kalan 4021 metrelik bir rakıma sahip OtgonTenger Dağ1 civarındaki Ötüken bölgesi olmuştur. Çünkü güneyinden Hangay Dağı, kuzeyden de Tamır Irmağ1 ile çevrili olan bu bölge tabii ve yüksek bir kale niteliğindeydi ${ }^{2}$. Buraya yapılan göç akını bölgedeki popülasyonu arttırmış dolayısıyla sosyolojik açıdan yeni bir düzenin kurulması ihtiyacı doğmuştu.

Ötüken bölgesine yerleşen bu kabileler kesinlikle tek bir soydan gelmiyordu. Hatta Gumilev' in ifadesiyle Türk adıyla anılan kabileler topluluğu tarih sahnesine çıktığında herkes Türkçe

\footnotetext{
${ }^{27}$ Ahsen Batur, 1200 Yillık Sürgün "Türk" Adının Hazin Serüveni, s. 11.

${ }^{28}$ Aydın Taneri, Türk Devlet Geleneği Dün-Bugün, s. 27.

${ }^{29}$ Adem Aydemir, “Ötüken ve Ötüken Adı Üzerine” Türk Dünyası Araştrrmaları

Dergisi, sayı:187, 2010. s. 198.
} 
konuşmuyordu, kabileler arasındaki ortak dil Siyenpi dili idi ${ }^{30}$. Buradaki kabileler genel olarak demircilik yaptıklarından o sırada Orta Asya steplerini yağma ve saldırılarıyla kırıp geçiren bir güç olan Juan-Juanlar'a haraç olarak demir işleyip veriyorlardı. Bu ortamda Hun orjinli Bumin bu bölgedeki halkları birleştirerek JuanJuanlar'a karşı vergi vermeyi reddetti. Yaklaşık 50 bin çadırlık Uygurlarla birleşerek 552 yılında beklenmedik bir anda Juan-Juanlar'a saldırıp onları yendi. Bu zaferden sonra kendisine İl Kağan unvanını alarak I. Türk Hakanlığını resmen kurmuş oldu.

Bumin Kağan'nın kurduğu devlet o güne dek kabile devletleri şeklinde oluşan bozkır örgütlenmeleri yanında bir devrim niteliği taşıyordu. Zira Bumin Kağan kabileleri birleştirdiği ortak hukuka töre adını verdi ve bu hukuku kabul eden kabileler artık "Törük" olarak isimlendirilmeye başlandı. Türklerin dip ataları oldukları düşünülen Hunlarda Hun ulusundan sayılmak için herhangi bir Hun boyunun üyesi olma şartı aranıyordu. Ya da evlilik yoluyla ve Kağan'ın buyruğuyla urukların Hun ulusuna kabul edilmesi sağlanıyordu. Otorite açısından Hunların halefleri olan Göktürkler ise devletin hukukunu kabul eden bütün kabileleri Türk ulusunun üyeliğine kabul etmişlerdir ${ }^{31}$.Bu tespitler ş̧ığında Türk adının bir soyun ya da boyun adı olarak değil bir kabileler konfederasyonun ortak ismi olarak ortaya çıktığını söyleyebiliriz. Zira Ziya Gökalp de Türk sözcüğünün anlamını "Türeli” yani töresi olan biçiminde kabul etmiştir ${ }^{32}$. Aslında Türkiye Cumhuriyeti'ne anayasal vatandaşlıkla bağlı olan herkese dil, din ve ırk farkı gözetilmeksizin "Türk" denilmesi aynı felsefenin çağdaş döneme yansımasıdır. Yani Türk adı ne tarihte ne de çağdaş dönemde bir etnik yapıyı simgelemediğini bilakis etnik yapıların uzlaşısı üzerine kurulan büyük bir birlikteliği tanımladığını söylemeliyiz. Ayrıca bu siyasi kimlik tarihte hiçbir şekilde kendisini oluşturan küçük etnik yapıları yok saymamış, bu etnik yapılar Türk kimliği içerisinde varlıklarını sürdürmüşlerdir.

\footnotetext{
30 Gumilev, Eski Türkler, Aktaran, Mehmet Akif Okur “Büyük Kimliğin İzinde: Genişleme Çağları Ergenekonlar ve Türklük". Bkz. Orta Asya'da İslam Temsilden Fobiye, C. I, s. 304.

${ }^{31}$ Gumilev, Etnogenez Halklarm Şekillenişi, Yükseliş ve Düşüşleri, s. 96.

${ }^{32}$ Ziya Gökalp, Türk Medeniyeti Tarihi, s. 27.
} 
Örneğin Göktürk Hakanlığının etnik unsurlarından biri olan Basmıllar 744 Türk Hakanı Ozmış'1 tuzağa düşürmüşler, kellesini kesip Çin Hükümdarına hediye etmişlerdir. Aynı yıl Göktürklerin bir uruğu olan Uygurlar da Baymey adındaki yeni kağanın kellesini Çin Hükümdarına göndermişlerdir ${ }^{33}$. Bütün bu aktarımlardan sonra Göktürk Hakanlığı ya da Büyük Türk Hakanlığının kuruluşunun yine sosyolojik bir gerekçe ile olduğunu ve bu örgütlenmenin Türk adını sahneye çıkardığını görmüş olduk. İkinci Türk Hakanlığının tarihi serüveni de birincisine benzeyecektir. Fakat burada artık Türk adı Birinci Hakanlığın mirası olarak kullanılacaktır. Fakat yine benzer bir ortamda benzer bir gerekçeyle kurulacaktır.

Türk adının anlamı ve tarih sahnesine çıkma gerekçesini özetledikten sonra Türklerdeki egemenlik anlayışının mitoslarda yer eden köklerini belirlemek için Türk mitolojisinin temel unsurlarına değineceğiz.

Orta Asya bozkırlarında mitolojik dönem araştırmaları M.Ö. 10 ile M.Ö. 250 yılları arasında hüküm sürmüş ve hükümranlıklarını Kırım' a kadar genişletmiş olan İskitlere kadar uzanır. İskitlerin Hunların ve Türklerin ataları olduğu tarihçiler arasında ihtilaf konusu olsa da İskit kültürünün bölgede oluşan diğer halkları etkilediği bir gerçektir. Araştırmacılar göçebe bir toplum olan İskitlerde doğanın kutsallaştırılmasına bağlı olarak tek tanrı inancının geliştiğini, bunun yanında çevrelerinde var olan yerleşik kültürlerin etkisiyle çok tanrılı bir panteona da sahip olduklarını kabul etmektedir ${ }^{34}$. Asya Hunlarının inancı da yine doğanın belirli unsurlarını kutsanmasını içermekle birlikte tek tanrı inancına yakın duoteist yani iki tanrılı bir sistemdi ${ }^{35}$. Hunların inanç sistemi güneşi tek tanrı olarak kabul ediyor fakat güneşle birlikte aya da kutsallık veriyordu. Kaynaklar Hun hükümdarlarının kampın dışında sabah güneşe akşam vakti ise aya saygı gösterip tapındıklarını belirtmektedir. Öte yandan Hun inancında gök, yer ve atalar kutsal sayılıyor ve onlar için yılın belirli günlerinde ritüeller düzenleniyordu. Ayrıca Hunlara göre güneş ve ayın emriyle yer ve gök hükümdarlarını

\footnotetext{
33 Batur, 1200 Yıllık Sürgün "Türk” Adının Hazin Serüveni, s. 35.

34 İbrahim Çeşmeli, “Tarihi Kaynaklara Göre Türk Göçebelerinde Dinler, Kültler, Ritüeller ile İkonografi M. S. 8. Yüzyıla Kadar", Art-Sanat Dergisi, S. 3, s. 49
}

35 Çeşmeli, “Tarihi Kaynaklara Göre Türk Göçebelerinde Dinler, Kültler...”, s. 49. 
doğuruyordu ${ }^{36}$. Hunların gök, yer ve atalar kültleri Orta Asya halklarının dolayısıyla Türk mitolojisinin temel unsurlarını oluşturduğu eski Türk dini ve mitolojisi üzerinde araştırma yapanların ortak kanaati olmuştur.Orta Asya mitolojisinin Göktürkler dönemine gelinceye dek biçimsel bir evrim geçirdiği görülecektir çünkü Türklerin (Göktürkler) inancı doğanın belli unsurlarını kült haline getirmiş olsalar da monoteist bir yapıdayd ${ }^{37}$. Önceleri saygı duyulan ve kutsal sayılan gök Türklerde tek yaratıcı tanrı kimliği kazanmıştır. Fakat bu konuda göğün tanrılaştırılmasından ziyade tanrısallaştırılmasından yani kutsanmasından bahsetmenin daha doğru olacağı kanaatindeyiz. Çünkü gök göçebe toplumlar için uçsuz bucaksız görüntüsü ve erişilmezliğiyle her şeyin yaratıcısı olan aşkın bir ilahın sıfatlarıyla özdeşleştiriliyordu. Gök bu anlamda tanrının aşkınlığını ve yüceliğini anlatan bir semboldü bizatihi tanrı değildi. Baş kutsala bağlı olarak kutsanan bir değerdi. Zira Tanrının gökte olduğu inancı Ortadoğu mitolojilerinde de hatta semavi dinler dediğimiz dinlerde de karşımıza çıkacaktır. Hatta son din İslam'da bile Allah'ın gökte bir tahtının olduğu ve bu tahta kurulduğu mitosu kullanılmıştır. Bunun amacı Allah sizi her daim gözetliyor ve yaptıklarınızdan haberdardır düşüncesinin dönemin akıl yapısına göre metaforik bir anlatım olduğu aşikardır.

Türk Mitolojisine geri dönecek olursak bu mitolojinin temelde her şeyi yaratan aşkın bir tanrı, gök kültü, yer-su kültü ve atalar kültü olmak üzere dört temel unsurdan oluştuğu görülür. Ayrıca Türk kültüründe yaratılış ve türeyiş efsaneleri de mevcuttur. Yaratılış Tanrıyla, türeyiş ise atalar kültü ile ilişkili olduğu için bu efsaneleri bu başlıklar altında zikredeceğiz.

\section{Din ve Mitoloji Arasında Eski Türk Kültürü}

Konuyu Türk kültürüne getirmeden önce din ve mitoloji arasında bir ayrım yapmak gerektiğine inanıyoruz. Çünkü tarihle efsanelerin iç içe geçtiği gibi dinler alanında araştırmalar yapanlar din ile mitoslar arasında da kalmış son derece kompleks bir yapı ile karşı karşıya gelmektedirler. Bilindiği üzere din sözcüğü dilimize Arapçadan geçmiştir. Türk Dil Kurumu'nun sözlügüunde “Tanrıya

\footnotetext{
${ }^{36}$ Çeşmeli, “Tarihi Kaynaklara Göre Türk Göçebelerinde Dinler, Kültler...”, s. $57-58$

${ }^{37}$ Çeşmeli, “Tarihi Kaynaklara Göre Türk Göçebelerinde Dinler, Kültler...”, s. 50
} 
ve doğaüstü güçlere inanmayı, çeşitli kutsal varlıklara tapınmayı sistemleştiren toplumsal bir kurum, bu nitelikteki inançları kurallar, kurumlar, töreler ve semboller biçiminde toplayan düzen" olarak tanımlanmaktadır ${ }^{38}$. Terimleşmiş ifadesiyle bir inanç ve ibadet yasaları sistemi olan din sözcügüüün köken itibariyle Akat dilindeki "yasa ve yarg1" anlamına gelen "dinu" sözcügüunden alıntı olduğu görüşleri de vardır ${ }^{39}$. Ziya Gökalp her ne kadar eski Türklerin dine nom, kutsal metinlerine num adını verdiğini aktarsa da bu dinin ruhani başkanına toyon, kahin ve büyücülerine ise kam (şaman) denildiğini söylemektedir. Ayrıca Şamanizm denilen bu nom sisteminin eski Türklerde kehanetin ve ruhsal tıbbın ismi olduğunu beyan etmektedir ${ }^{40}$. Bu bağlamda Gökalp'in nom adını verdiği sistem ilkel üstü toplumları örgütleyen bir nitelikteki din kavramını karşılamamaktadır ${ }^{41}$. Zaten Gökalp bu sistemin totemcilik döneminin dini olduğunu söylemektedir. Toplumsal düzeni sağlaması itibariyle Eski Türklerde din kavramını karşılayan sözcüğün "töre" olduğu söylenebilir. Törenin tanrısal bir niteliğe sahip olması ve devletin bütün unsurları arasında ortak inanç ve yasayı temsil etmesi bu bağlamda düşünülmelidir. Ayrıca İbranicedeki “Torah" sözcüğü de törenin Türkçedeki anlamı karşılayan "yasa, din, şeriat" anlamında olduğu bilinmektedir. Bu sözcügüun Arapça söylenişi Tevrat şeklinde olmuş ve Yahudilerin kutsal metinlerinin adı olarak anlam kazanmıştır. Antik tarihçilerin kaydettiğine göre Tevrat'ın kendisine verildiğine inanılan Musa Aleyhisselam M.Ö. 1300'lü yıllarda yaşamıştır ${ }^{42}$. Bu sözcügüun ve aşkın tek tanrı inancının zaman içerisinde kültürel etkileşim yoluyla Orta Asya bozkırlarına taşınmış olması muhtemeldir. Ayrıca Gumilev'in etnos tanımına şart koştuğu "ortak davranış" kalıplarını oluşturacak olan ortak inanç,

${ }^{38}$ Bkz.http://www.tdk.gov.tr/index.php?option=com_gts\&arama=gts\&guid= TDK.GTS.5938846db2a649.11325018. Erişim Tarihi:07.06.2017.

${ }^{39}$ Bkz. https://www.etimolojiturkce.com/kelime/din. Erişim Tarihi:07.06.2017.

${ }^{40}$ Gökalp, Türk Medeniyeti Tarihi, s. 25.

${ }^{41} \mathrm{Bu}$ bağlamda Musa Aleyhisselam'ın risaletinden sonra İsrailoğullarının teşkilatlı bir ulus olarak tarih sahnesine çıktığını, kabileler halinde birbiriyle savaşarak düzensiz ve asayişsiz bir yaşam süren Arapların Hz. Muhammed'den sonra teşkilatlı bir millet olup, büyük bir medeniyet oluşturduklarını anımsamak gerekir.

${ }^{42}$ Robert Wintson, Tanrının Öyküsü Tanrı mı İnsanı, İnsan mı Tanrı'yı Yarattı, s. 13. 
ortak alg1 ve ortak yasa gibi ilkeler ancak din denilen kurumda mevcuttur. Dine kıyasla mitoslar dağınık inançlardır ve politik birliğini oluşturamayan toplumların evren anlayışını yansıtır. Dinleri ise insanları dağınık ve düzensiz bir yaşantıdan düzenli ve medeni bir yaşantıya geçiren öğretiler ve yasalar bütünü olarak kabul etmek gerekir. Zira mitolojik ve Helenistik kültür döneminde anarşik bir yapıda yaşayan Avrupa ve Ön Asya toplumlarının Roma'nın Hristiyanlığı resmi din olarak kabul etmesinin ardından eskiye oranla daha istikrarlı ve daha güvenli bir yaşantıya geçtikleri bilinen bir gerçektir. Dinlerde rasyonel öğretilerle birlikte mitolojik unsurlarında bulunmasını dinlerin mitolojik dönemden teolojik döneme geçiş sürecini temsil etmeleri açısından doğal karşılamak gerekir. Zira monoteist dinler oluştukları süreç içerisinde eski dünyanın inançlarını da kullanarak eski dünyanın inançlarını ortadan kaldırma amacı gütmüşlerdir. Bu bilgiler ışığında diyebiliriz ki monoteizm teolojik bir teori olarak insanların bir arada, eşit hukuka dayalı, barış içerisinde yaşama idealini yansıtan bir inanç sistemi ve ideolojidir. Çünkü tanrının tek olması bütün insanların kökensel birliğine ve dünya nimetlerinden faydalanma konusunda aralarında fırsat eşitliğinin olmasına işaret etmektedir. İnsanlar temelde eşit olduklarına inanırlarsa temelleri sağlam bir toplum ve devlet oluşturabilirler. Monoteizm bu anlamda geçmişte kurulan devletlerin kurucu unsuru olarak kabul edilebilir. Temelde monoteist olan bir dinin ya da ideolojinin ilerleyen dönemlerde politeizme ya da Max Müller'in tabiriyle henoteizme ${ }^{43}$ dönüşmesi insanların yaşadıkları yozlaşmış hayatın mitolojik dönemi yeniden canlandırması olarak düşünmek gerekir. Zaten politeizm ve henoteizmin sınıflaşmış ve sınıflar arası geçişkenliğin neredeyse çok az olduğu toplumların dini olduğu pek çok araştırmacı tarafından kabul edilmektedir.

Bu yüzden eski Türk dinini ve mitolojisini incelerken tek tanrı inancını ve buna bağlı olarak yaratılış efsanelerini din kategorisinde, kültleri ve türeyiş efsanelerini mitolojik unsurlar kategorisinde değerlendireceğiz.

\footnotetext{
${ }^{43}$ Henoteizm: Teoride tek tanrıcılık uygulamada çok tanrıcılık biçiminde tezahür eden inanç sistemidir. Daha kolay bir anlatımla bol kutsallı tek tanrı dini olarak tanımlanabilir.
} 


\section{Eski Türk Dini ve Mitolojisi}

Bu bölümde inceleyeceğimiz konu Türk kimliğini kullanan Göktürklerle sınırlı olacaktır. Zira Türklüğü siyasi bir kimlik olarak kullanan kozmopolit boylar bileşkesinden bir ulus oluşturan bu devletin ve toplumun dini ve sonrasında mitolojiye dönüşmesi araştırmamız açısından daha fikir verici sonuçlar doğuracağı düşünülmektedir. Çünkü Göktürklerin oluşturduğu ulusun urukları Göktürkler yıkıldıktan sonra bile her ne kadar kendilerini Türk olarak düşünmeseler de ve Türk adını kullanmasalar da diğer milletler tarafından hep Trük adıyla anılacaktır. Bumin Kağan'ın farklı boyları "töre" çevresinde birleştirip onlara ortak isim olarak Törük ya da Türk adını vermesi bozkır göçebe toplumlarında o güne dek görülmeyen bir devrim olmuştur. Bu ortak hukuk işletildiği sürece Göktürkler varlıklarını bütün görkemiyle sürdürmüşler. Yani monoteizmin birleştirici gücünün meyvelerini yemişler, ortak hukuk terk edilince, sınıflar ve boylar arasında ayrıcalıklı hukuk oluşmaya başladıktan sonra devletlerini kaybetmişlerdir.

\section{a- Eski Türk Dini}

Eski Türk dininin daha önce belirttiğimiz gibi en önemli unsuru tek tanrı inancıdır. Pek çok araştırmacı semavi bir yüce tanrıya inancın ilkel toplumlarda bile oldukça yaygın olduğu kanaatindedir. Öyle ki Viyana Etnografya Ekolü ve bu ekolün önde gelen isimlerinden W. Schmidht bu vakıaya dayanarak insanlığın dini tarihi içerisinde sürekli bir monoteizmin varlığından söz etmiştir ${ }^{4}$. İnsanlığın ilkel döneminde bile insanları aşkın bir tanrının varlığını kabul etmeleri yeryüzünün diğer sakinlerinden farklı olmaları nedeniyle kendilerine doğanın dişında bir köken arama böylece varlıklarını anlamlandırma çabalarının bir göstergesidir. Zira insan aklının temel bir özelliği vardır ki o da olaylar ve olgular arkasında bir neden aramadır. Bu özellik sırandan gözükse de insanın bütün düşünce ve inanç dünyasını oluşturan zihinsel hatta güdüsel bir payandadır. Bu neden arama özelliği onun kendisini ve evreni yaratan bir yaratıcı Tanrının bulunduğuna götürmüştür. Günümüzde Tanrı inancı top-

${ }^{44}$ Ünver Günay ve Harun Güngör, Başlangıçtan Günümüze Türklerin Dini Tarihi, s. 33 
lumsal bir dayatmayla ya da kutsal metinlerin otoritesi ile insan zihninde biçimlendirilmeye çalışıldığ için bu düşünsel keşfin etkisi ve gücü günümüz insanında gereken etki ve işlevi göstermediği açıktır $^{45}$. Kısacası diyebiliriz ki insanlar ortak kökenlerini nesnel olarak tanımlayan yaratıcı Tanrıyı keşfetmişlerdir.

İnsanların yaratıcı ilahı keşfetmeleri bir başka sorunu daha ortaya çıkarmıştır. Bu Yaratıcı İlah fikri toplumsal düzlemde nasıl işleyecektir. İşte monoteizmin, politeizmin ve henoteizmin ayrıştığ 1 nokta burasıdır. Monoteizme göre Tanrı herkesin tanrısıdır, tek kutsaldır, eski dünya inanışlarına göre göktedir çünkü insanların ne yaptıklarını gözetlemektedir. İyiyi mükâfatlandıran, kötüyü cezalandıran niteliktedir. İnsanları o yaratmıştır ve bütün insanların kökeni odur. $\mathrm{Bu}$ inanç sistemine göre Tanrı kimsenin tekelinde değildir, kimsenin akrabası değildir. İnsanlar arasındaki ilişkilerde hakem pozisyonundadır. Kimse onun katında ayrıcalığa sahip değildir. Bu inanç insanlar arasında adaleti sağlamanın temelidir. Bu inancı muhafaza eden ve bireyleri arasında işleten toplumlar ve devletlerin ömrü uzun olmuştur. Fakat her inancın doğası gereği zaman içerisinde bireylerin farklı yaşam deneyimlerine bağlı olarak, insanlar üzerindeki egemenlik isteği, güç istenci, daha fazla rant devşirme gibi nedenlerle monoteizm de dejenarasyona uğramış etkisini yitirince mitolojik dönemin inançları olan politeizm ve henoteizm toplumlarda yeniden ortaya çıkmıştır. İnançlar efsaneleşmiş, insanlar arasındaki sınıflaşmalar ve kamplaşmalar tanrılar (politeizm) ya da tanrıya bağlı kutsallarla (henoteizm) kutsanmıştır. $\mathrm{Bu}$ inanç dönüşümleri doğal olarak toplumların tarih sahnesinden silinmesinde büyük rol oynamıştır. Yani monoteizm toplumlarda birliği ve dirliği sağlamış, politeizm ve henotezim ise kamplaşmayı, ayrışmayı, çatışmayı yükseltmiş ve dolayısıyla toplumsal çöküşler kaçınılmaz olmuştur.

Bu paradigma içerisinde Göktürkleri tarih sahnesine çıkaran sistemin monoteizm olduğunu söylemek sanırım yanlış olmaz. Monoteizmin aynı zamanda toplumsal uzlaşı ve birlik anlamına geldiğini Orta Asya'da devlet kuran bütün Türk hanedanlarında bu inancın yer almasına dönük bilgiler bu teoriyi ispat eder nitelikte-

${ }^{45}$ Bal, Aykırı Sesler Teolojik ve Yarı Politik Denemeler, s. 55. 
dir. Bu durum bazı araştırmacıları Gök Tanrı inancının “İmparatorluk Tanrısı" olduğuna dönük değerlendirmelere sevk etmiştir. Nitekim "Tarihte ve Bugün Şamanizm" adlı çalışmasında Afet İnan Türklerin büyük imparatorluklar kurduğu dönemlerde Gök Tanrı inancının imparatorluğu oluşturan bütün uruklar için müşterek bir kült olduğunu belirtmiştir ${ }^{46}$. Aynı şekilde J.P. Roux Türk dini sisteminde devlet dini ile halk inançları arasında bir ayrım yapmış Türklerdeki Tanrı anlayışının devletin şekline bağlı olarak azalıp çoğaldığını, imparatorluk dönemlerinde Tanrının tekleştiğini ancak imparatorluklar parçalandıktan sonra Tek Tanrının dağıldığını çok tanrıcılığın ortaya çıtığını söylemektedir.

Türklerin imparatorluk döneminden kalan yazıtlarında Gök Tanrı tüm azameti ile birinci planda yer almakta Türk dini her şeyden önce Tek Tanrı etrafında şekillenmektedir. Metinlerde Gök Tanrı kudretli, aşkın ve yüce bir ilah olarak kendini göstermektedir. Kozmik düzenin, dünyanın ve toplumun organizasyonunun, insanların kaderlerinin Tanrıya bağlı olduğu anlaşılmaktadır ${ }^{47}$. Göktürkler döneminde kitabelere yansıdığ 1 kadarıyla Tanrının yaratıcı ve Kadir-i Mutlak olarak algılandığı görülür. Örneğin Kağanlar Tanrı irade ettiği için kağan olmuşlardır. Bu konuda değinilmesi gereken başka bir nokta Türklerin aşkın Tanrı inancına ulaştıklarıdır. Çünkü Gök Tanrı adına herhangi bir tapınağın yapıldığı bilgisi mevcut değildir, herhangi bir biçimde resmedilmesi ve heykellerinin yapıld1ğına da rastlanılmamıştır ${ }^{48}$.

Gök Tanrı Türk dininde dünyayı bir kere yaratıp sonra bir kenara çekilen nitelikte değildir. Bununla birlikte Sami kültüründeki Tanrı inancı gibi her şeye müdahale eden bir nitelik de taşımaz. Olaylara doğrudan olmaktan çok dolaylı müdahale eder, Tanrının insanların hayatına müdahalesi doğa güçleriyle olur. Orta Asya'da Moğollar dönemine gelince Gök Tanrı inancı yeryüzüne müdahile etmeyen bir niteliğe (Deus Otiosus) evrilmiş, bunun sonucunda

\footnotetext{
${ }^{46}$ Günay ve Güngör, Başlangıçtan Günümüze Türklerin Dini Tarihi, s. 37.

${ }^{47}$ Günay ve Güngör, Başlangıçtan Günümüze Türklerin Dini Tarihi, s. 37.

${ }^{48}$ Günay ve Güngör, Başlangıçtan Günümüze Türklerin Dini Tarihi, s. 38-39.
} 
yaygın kutsal dağılarak 99 tanrı anlayışıyla henoteizm geri gelmiş$\operatorname{tir}^{49}$.

Birinci Göktürklerin varisi olan İkinci Göktürklerden kalan Orhun yazıtlarına baktığımızda da tek Tanrı inancını bütün açıklığıyla görürüz. Tanrı şafakları söktürendir, bitkileri meydana getirendir. Hayat verici ve yaratıcıdır. Ölüm de hayatı veren bu Tanrının dilemesine bağlidır ${ }^{50}$.

Bütün bu bilgiler ışığında Orta Asya toplumlarında var olan Tanrı inancının Göktürkler dönemine kadar evrim geçirdiği. Birinci Göktürk Devleti'ni kuran iradenin etnik ve kabilesel bütün kutsalların üstünde Tek bir Tanrı'yı devleti oluşturan unsurlar arasında ortak iyiyi, ortak kökeni ve ortak hukuku temsil eden bir inanç ve sembol olarak kabul ettiğini, bu Tanrı inancına bağlı olarak onun iradesinin yansıması olan "Töre" yi yani dini insanlar arasında ortak değer olarak benimsedikleri sonucuna ulaşabiliriz.

Yaratılış kokusuna gelince burada dünyanın değişik kültürlerinde var olan bütün öykülerin mitolojik unsurlarından ziyade neyi temsil ettiği üzerinde durmanın daha doğru olacağ 1 düşüncesindeyiz. Çünkü mitolojik unsurlar içermesine karşın yaratılış bütün dinlerde insanların ortak kökenini ve ontolojik eşitliğini simgeler. Ontolojik eşitsizliği simgeleyen anlatılar ise türeyiş efsaneleridir. Tek Tanrı inancı ile yaratılış düşüncesi paraleldir. Çünkü Tanrı fikrine ulaşan insan aklı doğal olarak varlıkların onun tarafından var edildiği düşüncesine ulaşmıştır. İslam filozofları buna "eserde müessiri görmek" terimini üretmişlerdir ${ }^{51}$. Bu Tanrı tarafından yaratılma inancı “Üstte mavi gök, altta yağız yer kılındıkta ikisi arasında kişioğlu kılınmış" sözleriyle Orhun Yazıtlarında net olarak görülür ${ }^{52}$. Bütün dinlerdeki yaratılış öykülerinin işlevi insanların kökensel birliğini, dolayısıyla eşitliğini vurgulamaktır. Çünkü sosyal bir kurum olarak dini işlevi bütün fertlerinin eşit olduğu, kimsenin kimseye ontolojik ve hukuksal üstünlüğünün olmadığı bir toplum

\footnotetext{
${ }^{49}$ Günay ve Güngör, Başlangıçtan Günümüze Türklerin Dini Tarihi, s. 41-43.

${ }^{50}$ Kültigin Kitabesi, Kuzey,10. Aktaran: Selim Karakaş. “Türklerin Orijinal Dinleri Meselesi" Gaziantep University Journal of Social Sciences, 13/2, s. 466.

${ }^{51}$ Bal, Aykırı Sesler Teolojik ve Yarı Politik Denemeler, s. 56.

${ }^{52}$ Bkz. Bilge Kağan Yazıtı, Doğu Yüzü, 2. http://www.gokturkce.net/yazi/bilgekagan-yaziti-cevirisi-okuma-metni/ Erişim Tarihi:08.06.2017.
} 
oluşturmaktır. Bu vurgu son monoteist din İslam'ın Kutsal Kitabı'nda ve Hz. Muhammed'in sözlerinde siklıkla vurgulanan bir temadır. Örneğin Hz. Muhammed'in insanlar için "Abdullah" yani "Allah'ın kölesi" kimliğini öne çıkarması köleliğin ve köleleştirmenin gelenek olduğu bir toplumda "kimse kimsenin kölesi değildir, kimse kimseyi köleleştirme hakkına sahip değildir, çünkü herkes Allah'ın kölesidir" mesajını içermesi son derece önemli bir gerçeğin vurgulanmasıdır. Zaten İslam inancı oluştuğu dönemin koşullarına

göre okunduğunda insanların Allah'ın yarattığını ve Âdem'den türediklerini söyleyerek aralarındaki ontolojik eşitliği daima dile getirmiştir.

Bu bağlamda eski Türklerdeki tek Tanrı ve Yaratılış inançlarını dinleri kapsamında değerlendirmek gerekiyor. Çünkü her iki kavram da insanların eşitliğini öngören metafiziksel de olsa işlevleri açısında rasyonel birer öğretidir. Halk inanışları düzeyinde değerlendireceğimiz kültleri mitoloji kapsamında değerlendireceğiz.

\section{b- Türk Mitolojisi}

Çağdaş İslam Düşünürlerinden merhum Muhammed Abid el-Cabiri "Arap-İslam Aklının Oluşumu" adlı eserinde yükselen yeni bir kültürün kadim kültürü ve inanışları baskıladığını fakat hiçbir zaman yok edemediğini, yükselen kültürün gelişmeyi bıraktığı dönemde atıl akıl olarak nitelediği eski inançların yeni kültürün bir parçası olarak yeniden ortaya çıktığını belirtir. Bu açıdan baktığımızda Türk kimliğini ortaya çıkaran Göktürklerin oluşturduğu tanrısal ilkelere dayalı devletin ve töresinin Orta Asya'daki mitolojik unsurlara dayalı inanç sistemini, hukuk ve egemenlik anlayışını bir süreliğine rafa kaldırdığını söyleyebiliriz. Bumin ve İstemi gibi Göktürk kağanlarının töre kavramını devletin temel unsuru yapmaları töreyi benimseyen herkesi "Törük" diyerek hukuksal anlamda eşit kabul etmeleri ve kurdukları sistemin uzun süre devam etmesi bunun apaçık göstergesidir. Ayrıca Orhun Yazıtlarında Tanrı, Töre ve insan dışında mitolojik sayılabilecek ögelere az rastlandığı görülmektedir. Başkent olarak Ötüken'in kutsal sayılması bütün kültürlerde ve dinlerde var olan ortak kutsal yer olarak kabul edilmesi 
gerekir ${ }^{53}$. Fakat Göktürk devleti zayıflayınca, varlığını sürdürmek, eldeki mevcuda sarılmak hem de devleti adil bir düzlemde yönetemeyen kağanların egemenliklerini meşrulaştırmak için yaratılış öyküsünün yerine türeyiş efsanelerinin, yer-su ve atalar kültlerinin aldığı düşünülmektedir. Yani devleti güçlü kılan ve toplumu bir arada tutan rasyonalite kaybolunca, halkı öykülerle beslemek hatta avutmak tarih boyunca bütün egemenlerin kullandığ ya da kullanmak zorunda kaldığı bir yöntemdir. Fakat adalet gibi rasyonelliğini yitiren bir devleti üretilen ya da yeniden gündeme getirilen mitolojiler ve eski kahramanlık öyküleri uzun süre ayakta tutamamıştır.

Türk mitolojisi bütün mitolojik sistemler gibi oldukça karmaşık bir yapıya sahiptir, bu yüzden biz makalenin konusuyla ilintili olması açısından Yer-Su kültleri, Atalar Kültü ve Türeyiş Efsaneleri konularına değineceğiz.

\section{Yer-Su Kültleri}

Yer-Su kültleri dediğimiz inanç biçimleri Türklerin dini tarihleri içerisinde mevcut olan halk inanışlarını betimleyen bir terimdir. Buna tabiat güçlerine inanma ve kutsama da denebilir. Eski Türkler doğa da bir takım güçlerin bulunduğuna inanmışlar ve onları kutsallaştırmışlardır. Bu inançların hangi dönemde ve ne şekilde ortaya çıktığı net olarak saptanamamıştır ${ }^{54}$. Fakat dinlerin evrimi kapsamında animist dönemin inançları kapsamında değerlendirilebilir. Animizmi yani ruhçuluğu kısacası ölenlerin sonsuza dek dünyadan ayrılmadıkları, ruhlarının cenazenin çevresindeki ağaçlarda, bitkilerde ve giderek tüm doğada dolaştıkları böylece tüm doğanın canlı olarak algılanması olarak tanımlayabiliriz ${ }^{55}$. Bu inancın yansıması olarak Türklere göre tabiatta mevcut olan dağ, ağaç, su, kaya gibi nesnelerin birer ruhunun bulunduğu tasavvur edilmekteydi. Bunun yanı sıra güneş, ay ve yıldız gibi gök cisimlerine, gök gürül-

53 Örneğin Olympos Dağı bütün Yunanlıların, Beş İlahi Dağ Çinlilerin, Yeruşelim yani Kudüs İsrailoğullarının, Mekke ve Kabe eski dönemde bütün Arapların ortak kutsal yerleriydi.

${ }^{54}$ Günay ve Güngör, Başlangıçtan Günümüze Türklerin Dini Tarihi, s. 45.

${ }^{55 E r m a n ~ A r t u n, ~ " T u ̈ r k l e r d e ~ I ̇ s l a m i y e t ~ O ̈ n c e s i ~ I ̇ n a n c ̧ ~ S i s t e m l e r i-O ̈ g ̆ r e t i l e r-D i n l e r " ~}$ Kaynak Site: http://docplayer.biz.tr/1243560-Turklerde-islamiyet-oncesi-inancsistemleri-ogretiler-dinler.html. Erişim Tarihi:09.06.2017, s. 2. 
tüsü, şimşek gibi göksel olaylara da inançsal anlamlar yüklenmekteydi ${ }^{56}$. Gökalp'e göre Yer-Sular natürizm döneminde yerin ve suyun koruyucusu olduğuna inanılan tanrılard1 ${ }^{57}$.Ayrıca Eski Türklerdeki bu natürist inançlar için Orhun Yazıtlarında "Yer-Sub" kavramı kullanılmıştır. Yer-Sular kutsal kabul edilmekteydi. Günay ve Güngör'e göre Yer-Sular imparatorluklar döneminde gelişmiş ve vatan kültüne dönüşmüştür. Orhun Yazıtlarında "atalarımızın idare ettiği yer-sular" ifadelerinin geçmesi bunu açıkça göstermektedir ${ }^{58}$. Bu bağlamda Gök Tanrı inancının iktidarda olduğu dönemde bu tür inançların tapınmayı gerektirecek ayrı birer kült olmadığı baş kutsalın yani Tanrının evrenle ilişkisini sembolize eden doğal tezahürler olarak telakki edildiği düşünülmektedir.

\section{Atalar Kültü}

Ölmüş atalara saygı göstermek ve onlar için kurbanlar sunma inanç ve âdeti geleneksel Trük dininin en önemli görüntülerindendir. Atalar Kültünü oluşturan sistem kanaatimize göre yine animist akıldır. Animizme göre ebediyen dünyadan ayrılmayan ölülerin ruhları insanların arasına karışarak onlara şans verir, onları hasta edebilir. Bu yüzden ölülerin ruhlarını yatıştırmak için onlara adaklar adamak, kurbanlar sunmak ve ölmüş ataların mezarlarına sunularda bulunmak gerekir ${ }^{59}$. Öte yandan Atalar Kültü patriarkal (soyun babadan geçmesi) aile tipinin bulunduğu toplumlarda görünen dini bir gerçekliktir. Buna göre ölen ataların ve özellikle babaların ruhlarının geride kalanlara iyilik ya da kötülüklerinin dokunabileceği inancı ve onlara karşı duyulan minnet duygusu atalar kültünün temelini oluşturduğu düşünülebilir. Fakat burada atalar kültü ile ölüler kültü arasında bir ayrım yapmak gerekir. Eski Türklerde ölen her atanın ruhu kült konusu olmamaktadır, toplum içerisinde yalnızca saygıdeğer olan kişilerin ruhları kült derecesine ulaşabilmektedir ${ }^{60}$. Kült konusu olan ruhlar özellikle kabile ataları, ünlü savaşçılar ve

\footnotetext{
${ }^{56}$ Günay ve Güngör, Başlangıçtan Günümüze Türklerin Dini Tarihi, s. 45.

${ }^{57}$ Gökalp, Türk Medeniyeti Tarihi, s. 35.

58 Günay ve Güngör, Başlangıçtan Günümüze Türklerin Dini Tarihi, s. 46.

59 Artun, “Türklerde İslamiyet Öncesi İnanç Sistemleri...”, s. 2.

${ }^{60}$ Günay ve Güngör, Başlangıçtan Günümüze Türklerin Dini Tarihi, s. 52.
} 
din adamlarıyd $1^{61}$. Çeşmeli'ye göre atalar inancının göçebe toplumlarda ayrı bir yeri vardır. Yine Çeşmeli'nin aktardığı bilgilere göre VI. Yüzyıl'da Göktürk Kağanları toplumun soylularını her yıl kurbanlar sunmak için atalar mağarasına götürürd ̈̈̈ ${ }^{2}$. Çeşmeli bu eylemi yaratılış efsanesine dayandırsa da aktardığına göre gidilen mağara dişi kurttan türediklerine inandıkları mağaraydı, bu yüzden biz bu eylemin nedenini yaratılışa değil daha sonra inceleyeceğimiz türeyiş efsanelerine bağlıyoruz. Bunu yanı sıra arkeolojik kazılarda hem Hunlar hem de Göktürkler döneminde ülkelerinde atalar tapınaklarının bulunduğuna ilişkin sonuçlara ulaşılmıştır ${ }^{63}$.

\section{Türeyiş Efsaneleri}

Tarih öncesi insanların yaşama bakış açısı gelişim aşamalarından, bize bırakmış oldukları anıt ve araçlardan, efsanelerinden ve mitolojik öykülerinden anlamak mümkündür64. Başta Freud olmak üzere pek çok araştırmacı insan toplulukları arasında oluşan ilk inanç biçiminin totemcilik olduğu düşüncesindedir. Freud'a göre totem kural olarak yenebilen ya da korkunç ve tehlikeli bir hayvan, ender olarak bir bitki ya da yağmur suyu gibi bir doğa gücüdür. Kahinler her şeyden önce totemin bir klan atası olduğunu bilir. Ayrıca totem klanın koruyucu ruhu ya da gözetenidir. Kabileye güç katar ve yol gösterir, çocuklarını korur ${ }^{65}$. Ziya Gökalp Eski Türklerde değişik totemlerin varlığından söz etmiş Türklerde aynı adı taşıyan yer isimlerinin totem adı olduğunu söylemiştir. Hatta bu görüşünü biraz daha ilerleterek Hun ya da Kun sözcüğünün anlamının Orhun lehçelerinde koyun demek olduğunu belirterek Hunlar sözcügünü Koyunlular olarak anlamıştır66. Hunların koyundan türediklerine inandıklarına ilişkin elimizde bir veri olmasa da Freud'un görüşleri çerçevesinde Eski Türklerdeki türeyiş efsanelerini totemciliğin sonraki kültür içerisinde devam ettiğine ya da yeniden canlandığına bağlayabiliriz. Bu türeyiş efsaneleri içerisinde özellikle Göktürklerin ve Uygurların kurttan türeme anlatıları bu bağlamda değerlendirilebilir. Göktürklerin türeyiş destanına göre

\footnotetext{
${ }^{61}$ Bal, Aykırı Sesler Teolojik ve Yarı Politik Denemeler, s .97.

${ }^{62}$ Çeşmeli, “Tarihi Kaynaklara Göre Türk Göçebelerinde Dinler, Kültler...”, s. 62.

${ }^{63}$ Çeşmeli, “Tarihi Kaynaklara Göre Türk Göçebelerinde Dinler, Kültler...”, s. 62.

${ }^{64}$ Sigmund Freud, Totem ve Tabu, s. 11.

65 Freud, s.13

${ }^{66}$ Gökalp, Türk Medeniyeti Tarihi, s. 37.
}

260 
özetle Göktürklerin ataları bir düşman baskınına uğrayıp bütünüyle kılıştan geçirilirler. Aralarında yalnızca yaralı bir genç hayatta kalır. Düşmanlar onu da bulup kollarını ve bacaklarını keserler. Fakat genç ölmez ve onu dişi bir bozkurt bulup, sütü ile emzirir ve yaralarını iyileştirir. Sonra onu düşmanların bulamayacağı bir mağaraya götürür. Birlikte mağarada yaşarlar ve birleşirler. Sonunda on erkek çocukları doğar, çocuklar büyüyüp evlenince her birinden bir boy ortaya çıkar. Bu çocuklardan birinin adı Aşine'dir. Bu kardeşlerinin en akıllısı olduğu için Türklere kağan olur. Soyunu unutmadığı için çadırının kapısının önüne kurt başlı bir bayrak diker $^{67}$. Uygurların Türeyiş Efsanesine göre eski Hun hükümdarlarından birinin çok güzel iki kızı vardır. Hükümdar kızlarının güzelliklerinden dolayı ancak tanrılarla evlenebileceklerine inanmaktadır. Bu inancından dolayı kızlarını insanlardan uzak ülkenin kuzey tarafında bir kaleye kapatır. Derken Tanrı bir bozkurt kılığına girerek bu kızlarla evlenir. Bu kızlardan doğan çocuklar olan Dokuz Oğuz ya da On Uygur'un sesleri bozkurt sesine benzer ve bu çocuklar bozkurt ruhu taşıyarak büyürler ${ }^{6}$. Her iki destan da ortak tema yönetici sınıfın soyunu olağanüstü güçlere bağlamak ve tanrısallaştırmak olduğu görülecektir. Zira bir takım araştırmacılara göre Totemcilik ve bir tür Türk tipi animizm olan Şamanizm kabile döneminde Orta Asya halklarının dini mesabesindeydiler. Büyük imparatorluklar kurulduğu zamanlarda bu inançlar halk içerisinde devam etmiştir. Hunlar, Göktürkler ve Uygurlar gibi büyük devletler bir nevi kabileler konfederasyonu olduğu için her zaman dağılma tehlikesiyle karşı karşıyaydılar. Devletin birliğinin, gücü ve Kağan'ın iktidarının sürekliliği imparatorluğu oluşturan boylar ve beyleri tarafından sürekli tehdit altında olduğu için Kağanlar kabile ve halk inanışlarına saygı göstermişlerdir. Ancak imparatorluğun birliği için kabile dinlerini ve totemlerini ortadan kaldırmaya sadece Kağan boyunun totemini ortak totem haline getirmeye de çalışmışlardır ${ }^{69}$. Bu durumda mitolojik türeyiş efsanelerinin kağanlıkların

${ }^{67}$ Metin Turan, Türk Destanları, Açıköğretim Fakültesi Yayınları, Kaynak Site:https://fevzioz.files.wordpress.com/2014/01/acc4b1klama-destan2.pdf. Erişim Tarihi:10.06.2017, s. 56.

${ }_{68}^{6}$ Turan, Türk Destanları, s. 56.

${ }^{69}$ Günay ve Güngör, Başlangıçtan Günümüze Türklerin Dini Tarihi, s. 101. 
zayıfladığ1 dönemlerde iktidarın meşruiyetini sağlamaya dönük egemen boy tarafından alınan tedbirler olarak düşünülebilir.

Türeyiş efsanelerinin fonksiyonuna kısaca değindikten sonra Orta Asya'da devletlerin meşruiyet açısından dayandıkları en büyük mitolojiden bahsetmek istiyoruz. Bu mitoloji şüphesiz Oğuz Kağan efsanesidir. Oğuz Kağan efsanesinin Orta Asya'daki göçebe halkları birleştirip büyük bir devlet kuran Hun hükümdarı Mete'nin mitolojik öyküsü olduğu yönündeki düşüncemizi, onun topladığ 24 tümenlik askeri gücün sonradan 24 Oğuz boyuna dönüştüğünü daha önceki bölümlerimizde aktarmıştık. Oğuz Kağan adlı kişinin Tanrıdan kendisine armağan edilen kadınlarla evlenip çocuklarından 24 Oğuz boyunun türemesi, yaptığı savaşlarda Tanrının elçisi olarak kabul edilen bir bozkurdun kendisine yol göstermesi ekseninde dönen anlatı Orta Asya halklarını ve Türkleri derinden etkilediğini kabul etmemiz gerekir. Öyle ki Göktürklerden sonra Türk orijinli olarak kabul edilen halkların kendilerine Türk üst kimliğinden ziyade Oğuz kimliğini kullanmaları bunun en açık göstergesidir. Orta Asya'da Hunlardan sonra kurulan Göktürkler dışındaki bütün hanedanlar bir şekilde soylarını Oğuz Kağan'a dayandırmak zorunda kalmışlardı. Göktürkler daha önce belirttiğimiz gibi kurdukları devletlerin halklarına ortak bir siyasi kimlik olarak Türk adını kullanmışlardır. Fakat yıkılmaları kendilerini soy olarak Oğuz Kağan'a ve Hunlara dayandıran Uygurlar eliyle olduğunu da daha önce belirtmiştik. Kısacası Oğuz Kağan mitolojisini Orta Asya' da devlet kuran Türk orijinli halkların iktidarlarını meşrulaştırarak büyük devletler kurmalarını sağlayan bir anlatı olarak olumlu yönüne dikkat çekmek gerekir. Fakat söz konusu devletlerin içinde soyunu Oğuz Kağan'a dayandıran başka boyların da tahtı meşru hakları olarak görmesine neden olmuş, bu yüzden iç karışılıklar sonucunda bu devletler tarih sahnesinden daha erken silinmişlerdir.

\section{Türk Kültüründe Egemenliğin Meşruiyeti ve Mitolojiyle İlişkisi}

Makalemizin önceki bölümleri kapsamında egemenliğin mitolojik kökleri olsa da devletlerin öncelikle sosyolojik gereksinimler sonucunda oluştuğuna ilişkin varsayımımızdan dolayı her devletin dönemine rasyonel bir öğreti ya da ideoloji ile kurulduğunu, işleyişinde gerçekleşen sıkıntılar sonucunda ortaya çıkan itirazları ve muhalefet karşısında varlığını sürdürebilmek için egemenliğini 
sürdürebilmek için irrasyonel öğretileri de ideolojisine kattığ1 yönündeki değerlendirmelerimizi daha önce aktarmıştık. Zira büyük halk kitlelerinin itaatini kazanmak egemen sınıf için bir zorunluluktur.

Devlet ve egemen sınıf ortaya çıktığında kendini destekleyen halk birimlerini bir şekilde ikna etmiştir. Fakat araştırma konumuz eski dönem Türk devletleri ve özelde Türk adını siyasi olarak ortaya çıkaran Büyük Türk Hakanlığı (Göktürk Devleti) olsa da büyük bir devlet kurmak için o dönem bile kitleleri ikna etmek gerektiğini ve Göktürklerin bunu başardığını bir kez daha söylemekte yarar görüyoruz. Çünkü Göktürklerin Hunların mirasçıları olmalarına karşın siyasi terim olarak Hun adın kullanmamaları bu devletin kabilecilik, kavmiyetçilik ve asabiyet esasına göre kurulmadığını gösterir. Bu yüzden Göktürklerin kuruluş aşamasında egemenliği kaynağını "ortak kutsal" olarak kabul ediyoruz. Ayrıca devleti kuran hanedanın ilk temsilcisini de bu bağlamda cesaret, adalet, bilgelik, dürüstlük gibi bir insanların çoğunun bir araya getiremediği etik nitelikleri taşıması bakımından "doğal" bir önder olarak değerlendirmek gerekir. Egemenlik denilen güç ortaya çıktıktan sonra, ilerleyen dönemlerdeki hanedan temsilcileri artık doğal lider olmadıkları için ve kurucu liderin niteliklerinden bazılarını ya da hiç birini taşımadıkları için egemenliklerini irrasyonel söylencelerle meşrulaştırma yoluna gittikleri aşikârdır. Bu irrasyonel söylenceler başta atalar kültü olmak üzere türeyiş efsaneleridir. Türeyiş efsanelerini değerlendirirken bu konuda bir yanılgının olduğu düşünülmektedir. Türeyiş efsaneleri bir dikkatli incelendiğinde bir ulusun ortaya çıkışını değil, bir hanedanın egemenlik hakkını temsil ettiği görülecektir.

İbn Haldun'a göre bir devlet ancak güçlü olma ve başkalarına üstün gelme neticesinde kurulur. Başkalarına galip gelmek ise ancak gayret, tarafgirlik duygusu ve bir düşünce etrafında birleşerek o düşünceyi gerçekleştirmek için kararlılıkla çalışmak ve kalpleri birbirine kaynaştırmakla olur ${ }^{70}$. Ayrıca İbn Haldun kalpler hakka dönüp, asılsız ve sahte olanı terk ettiği ve Allah'a yöneldiği zaman insanların amaç ve hedeflerinin aynı olacağını, böylece insanlar ara-

70 İbn Haldun, Devlet, .s. 7 
sındaki rekabetin ortadan kalkacağını, anlaşmazlıkların azalacağını, güzel bir yardımlaşma ve dayanışmanın ortaya çıkacağını, bunun sonucunda devletin egemenlik ve otorite alanının genişleyeceğini ve güçlü olacağını söylemektedir ${ }^{71}$. İbn Haldun'un "Allah'a yönelmek" kavramı devletin oluşumundaki "ortak kutsal" tezimizi destekleyen mahiyettedir. Bu ortak kutsal Göktürk devletinin kuruluşunda monoteizme evrilmiş biçimiyle Tanrı idi. Zira toplumsal bağlamda Tanrı insanlar arasındaki yaratıcı niteliğiyle ortak kökeni, verdiği nimetlerle ortak iyiyi ve elbette ölüm gibi bir sonu getirdiği için ortak sonu temsil ediyordu.

Töre Tanrı'nın insanlar arasındaki ilişkilerde öngördüğü, barış ve dayanışma içerisinde yaşamaları için yararlı olan yasalar bütünüydü. Herkesin ortak otorite kabul ettiği bu ortak iyi değerin yasaları insanlar arasındaki ilişkilerde işletildiği sürece iyilik ve kötülük kavramları nesnel olacak ve dolayısıyla hukuk nesnel biçimde belirlenecekti. Töreyi uygulayacak kurum ise devlet ve devlet başkanıyd. Daha net bir ifadeyle söyleyecek olursak devlet ve töre Göktürklerde soyut ve aşkın olan Tanrının insanlar arasında hakem vazifesi görecek olan eliydi. Öte yandan devleti oluşturan o dönemki toplumun özlemleri, arayışları ve kültürel yapısıyla bağlantılı olarak devlet anlayışı insanlarca saygı duyulan ve Tanrıdan sonra en büyük otorite olarak görülmüş ve bu otoritenin kullanımı devlet başkanının şahsında kişileşmişti72 ${ }^{72}$ Diğer yandan Orhun Yazıtlarında günümüzde kullandığımız devlet kavramı yerine il terimi kullanılmıştır. İl terimi Divan-ı Lügati't-Türk'de barış olarak anlamlandırılmışıır ${ }^{73}$. Aynı biçimde Ziya Gökalp il kelimesini sulh anlamında olduğunu büyük aşiret kavgalarına son veren bir nitelikte olduğunu belirtmiştir ${ }^{74}$. Bu bağlamda halk kitleleri arasında barışı ve adaleti sağlama sorumluluğunu üstlendiğine inanan Türk Hükümdarlarının halkı yönetmek için Tanrıdan kut aldığını söylemeleri dönemleri içerisinde rasyonel bir söylemdi. Çünkü Kağanın vazifesi insanlar arasındaki adaleti ve barışı sağlamaktı ve Göktürk

\footnotetext{
${ }^{71}$ İbn Haldun, Devlet, s. 8.

${ }^{72}$ Bağdatl, Kutadgu Bilig'te Devlet ve Adalet İlişkisi, s. 3.

${ }^{73}$ Mehmet Naim Okur, Türk Devletlerinde Yöneten -Yönetilen İlişkisi ve İktidarın Meşruiyetinin Temelleri, Büyük Hun İmparatorluğu'ndan Tanzimat Fermanı'na Kadar, s. 8 .

${ }^{74}$ Gökalp, Türk Medeniyeti Tarihi, s. 36.
} 
devleti Hun Devletinin yıkılışından sonra ortaya çıkan otorite boşluğunun yol açtı̆̆ı adaletsiz, barışsız, yağmanın ve katliamların kol gezdiği bir anarşi ortamının sonucunda ortaya çıkmıştı. Bu ortama Tanrının eli değmesi gerekirdi, o da Tanrının töresi ideolojisi çevresinde kurulan Göktürk devleti olacaktı. Bu bağlamda Türk adını tarih sahnesine çıkaran Göktürk devletinin ideolojisini ortak kutsal ve ortak yasa olarak özetleyebiliriz. Yani son derece sosyolojik gerçekleri dikkate alan bir din olarak kabul edebiliriz. Hatta Kaşgarlı Mahmud'un eseri Divan-1 Lügati't-Türk'ün önsözünde “Tanrının devlet güneşini Türk burçlarından yükselttiğini" ve "Onlara Türk adını Tanrının verdiğini" söylemesi ilk Türk devleti olan Göktürk Hakanlığını oluşturan felsefenin sonraki yüzyıllara yansıyan bir söylemi olarak düşünülebilir.

Biraz konunun dışında da olsa devletin Tanrı ile özdeşleştirildiği eski inanç sistemlerinde insanlardaki Tanrı algısına yöneltilen eleştirilerin ve sunulan alternatif önerilerin gerçekte devletin niteliklerinin de bir tartışması olduğu sonucuna ulaşabiliriz. Özellikle ilk dönem İslam inanç ekollerinin tartıştı̆̆ 1 Tanrının sıfatları ve fiilleri konusu bu konuya örnek gösterilebilir. Ehl-i Sünnet kelamını oluşturan Eşarilerin Tanrıya Kadir-i Mutlak statüsünü vermeleri Tanrının yeryüzündeki halifesi olan muktedire de yaptıklarından sorgulanamaz bir egemenlik hakkı tanıyordu. Bu bağlamda siyasal iktidarın işine gelen bir söylem üretmişlerdi. Mutezile ekolünün Tanrının mutlak kudretini tevhid ve adaletle sınırlaması ise halifenin egemenliğini de sınırlayan siyasi bir mesaj taşıyordu. Ayrıca Mutezili bilginler siyasi meşruiyet arayışları çerçevesinde ortaya çıkan ve evrende tek failin Allah olduğunu öngören Ehl-i Sünnetin cebir ve kader doktrinine hür irade, istitaat ve sorumluluk temalarıyla karşı çıkıyordu ${ }^{75}$.

Konumuza geri dönecek olursak Göktürklerde hükümdarın Tanrıdan kut aldığı inancıyla ülkeyi yönetmesinin ona halkı üzerinde mutlak bir egemenlik hakkını verdiğini, denetimsiz bir otorite sağladığını düşünmenin yanlış olacağını belirtmek durumundayız. Zira Göktürk Hakanları kutu yani tanrısal yönetme yetkisini töreyle belirlenen tutum ve icraatlarıyla koruması gerekirdi. Eğer hükümdar devleti ve halkı zarara sokacak davranışlarda bulunursa, girdiği

${ }^{75}$ Mehmet Evkuran, Sünni Paradigmayı Anlamak, s. 250. 
savaşları kaybederek halkını zor durumda bırakırsa veya toplum vicdanına aykırı davranırsa kutunu yani toplumsal meşruiyetini yitirirdi. Bu kutun yitirilmesi bir kurultayla kağanın değiştirilmesi ya da bir başkaldırı sonucu hükümdarın değişmesi neticesinde olurdu ${ }^{76}$.

Devletlerin kurucu değerlerinin zaman aşımına uğraması, kurulan devletlerin zaman içerisinde egemen sınıfın güç kullanım aracına dönüştügü genel olarak eski devletlerin tarihinde görülen bir gerçekliktir. Bu noktada devlet artık toplumsal uzlaşının bir ürünü olan hakem müessese olmaktan çıkıp hanedanın görkem aracına ve ülke toprakları da hükümdarını dilediğine dilediği kadar bağışta bulunacağ 1 hatta veraset gereği çocukları arasında paylaştıracağı tapulu arazisine dönüşür. İşte bu noktada hanedanlar siyasi egemenliklerini sürdürmek için halk inanışları diyebileceğimiz mitolojik türeyiş öykülerine, rüya anlatılarına ve atalar kültüne başvurarak yeni meşruiyetler arama çabalarına giderler. Bu çabalar hanedanı ve devleti bir süre daha yapay bir solunum niteliğinde yaşatabilir fakat toplumsal yozlaşmayı ve çürümeyi aksine daha da arttırır. Bu bağlamda atalar kültü, türeyiş efsaneleri gibi inanışları egemenliği meşruiyetini yitiren hanedanların tutunmak zorunda kaldığ söylenceler olarak değerlendirmek gerekir. Fakat devletleri ortak değerlerin, ortak hukukun ve bunların güncellenmesi ayakta tutar, kutsal soy inancını önceleyen mitoslar, kutsal yurt söylemi üreten kültler tarih boyunca devletleri felakete sürüklemiş̧tir. Bu bağlamda Truva Atı öyküsünü hatırlamak gerekir. Özetle söylemek gerekirse Truvalıların tuzak olan atı şehre almaları efsaneleşmiş inançlarının ürünüydü. Zira bu efsaneleşmiş inançlarla hareket etmelerinin bedelini Truvalılar çok acı bir katliama maruz kalarak ödemişlerdir ${ }^{77}$.

Bu konuda Hun ve Göktürk devletlerinin kendilerinden sonra gelen kuşaklar için kutsal bir soy kültü miras bıraktıklarına da değinmek istiyoruz. Bu iki imparatorluktan sonra kurulan Türk devletlerinde hanedanların meşruiyetini soylarını bir şekilde Oğuzlara (Hun Bakiyeleri) ya da Aşinaoğullarına (Göktürk) dayandırdıkları Türk tarihçileri tarafından kabul edilen bir gerçektir. Örneğin Selçuklular Oğuzların Kınık, Osmanlılar Oğuzların Kayı boyundandır.

\footnotetext{
${ }^{76}$ Naim Okur, “Türk Devletlerinde Yöneten-Yönetilen İlişkisi...”, s. 11.

77 Bal, Aykırı Sesler Teolojik ve Yarı Politik Denemeler, s. 109.
} 
Cengiz İmparatorluğundan sonra ise oluşan kutsal han soyunun adı Hakanilerdir. Bir Özbek Beyi olan Timur'un şeceresini Cengiz Han'a dayandırma çabaları bilinmektedir. Yani Hun, Göktürk ve Cengiz devletlerinden sonra Türk Dünyasında kutsal bir han soyu ortaya çıkmış ve sonraki devletlerde egemenliğin meşruiyet aracı olarak halklar tarafından aranmıştır.

\section{Sonuç}

Türk kültüründe egemenliğin kaynaklarını incelediğimiz bu çalışmada devletlerin insanlar arasındaki ilişkilerin tanzim edilmesi açısında üst bir otorite arayışı neticesinde sosyolojik bir gereksinimden dolayı ortaya çıktığını varsayarak Türk adını siyasi olarak ortaya çıkaran Göktürk Devleti'nin kuruluş temellerini değerlendirdik. Ayrıca Türk kültüründeki egemenliğin kaynakları açısından önemli olduğu için Eski Türk Dininin ve Mitolojisini konumuzla ilgili olan esasları çerçevesinde incelemiş olduk. İncelediğimiz örneklemden yola çıarak diyebiliriz ki ilk Türk devleti olan Göktürklerin kuruluşunda egemenliğin kaynağı olarak toplumun ortak değerini yansıtan "Tanrı" ve "Töre" kavramları gibi o dönem için son derece rasyonel diyebileceğimiz birleştirici iki unsurdur. Yani Göktürk Devletinde egemenlik dinsel değerlere, töreye yani adalete bağl1lıkla ilişkilendirilmiştir. Fakat devletin işleyişi bu değerlerden uzaklaşınca egemenliğin meşruiyeti yer-su kültü, atalar kültü ve türeyiş efsaneleri gibi irrasyonel unsurlarda aranmıştır. Mitolojik unsurların bir devleti yaşatmaya hiçbir zaman yeterli olmayacağını hatta devleti ve halkı felakete sürükleyeceğine dönük düşüncemizi beyan etmiş olduk. Bu düşüncemizi Truva Atı öyküsüyle ilişkilendirdik.

Konuyu çağdaş dönemle ilişkilendirirsek, Türk kültüründe ve toplumsal hafızasında yer eden mitolojik ögelerin hala iktidara talip olan organizasyonlarca kullanıldığına tanık oluyoruz. Bu mitolojik unsurların en belirgini kutsanmış tarih anlayışıdır. Eski Türk Tarihi'nin, Osmanlı Tarihi'nin, ilk dönem Cumhuriyet tarihinin ya da İslam Tarihi'nin kutsanarak siyasi propaganda malzemesi yapılması çağdaş dönemdeki mitolojik anlatıların en belirginleridir. Ayrıca kadim Türklerdeki devletin Tanrıyla ilişkilendirilmesi ve Türk devletlerinin büyük kaosların sonucunda kurulduğuna dönük bil- 
gilerin örtük anlamda toplumsal hafızada yer alması kutsal tarih anlayışıyla birlikte çağdaş dönemde devleti başlı başına bir mitos haline getirdiğini de vurgulamak gerekir ${ }^{78}$.

\section{Kaynakça}

Artun, Erman, “Türklerde İslamiyet Öncesi İnanç Sistemleri-Öğretiler-Dinler"http://docplayer.biz.tr/1243560-Turklerde-islamiyet-oncesiinanc-sistemleri-ogretiler-dinler.html. Erişim Tarihi:09.06.2017.

Aydemir, Âdem, “Ötüken ve Ötüken Adı Üzerine” Türk Dünyası Araştırmaları Dergisi, sayı:187, 2010.

Bal, Şahin, Aykırı Sesler Teolojik ve Yarı Politik Denemeler, Mana Yayınları, İstanbul, 2017.

..........., Sorgulanmadan Sorgulamak, Mana Yayınları, İstanbul, 2015.

Bağdatlı, Özlem, Kutadgu Bilig'te Devlet ve Adalet İlişkisi. İstanbul Üniversitesi, Sosyal Bilimler Enstitüsü, Yayınlanmamış Yüksek Lisans Tezi, İstanbul, 2007.

Batur, Ahsen, 1200 Yıllık Sürgün "Türk" Adının Hazin Serüveni. Selenge Yayınları, İstanbul, 2013. Taneri, Aydın, Türk Devlet Geleneği Dün-Bugün, MEB Yayınları, İstanbul,1993

Beriş, Emrah H, “Egemenlik Kavramının Tarihsel Gelişimi Üzerine Bir Değerlendirme" Ankara Üniversitesi SBF Dergisi, cilt.63, sayı:1, 2008.

Bora, Tanıl, "Milli Tarih ve Devlet Mitosu". Birikim Dergisi, sayı:105-106, 1998.

Çeşmeli, İbrahim, “Tarihi Kaynaklara Göre Türk Göçebelerinde Dinler Kültler, Ritüeller ile İkonografi M. S. 8. Yüzyıla Kadar" Art-Sanat Dergisi, sayı:3, 2015.

Durant, Will, Medeniyetin Temelleri, çev. Necati Muallimoğlu, Boğaziçi Yayınları, İstanbul, 1978.

Etöz, Zeliha, "Mitos ve İktidar", Ankara Üniversitesi SBF Dergisi, cilt:66, sayı:3, 2011.

Evkuran, Mehmet, Sünni Paradigmayı Anlamak, Ankara Okulu Yayınları, Ankara, 2016.

Freud, Sigmund, Totem ve Tabu, Tutku Yayınları, Ankara, 2014.

Gökalp, Ziya, Türk Medeniyeti Tarihi, sadeleştiren: Yalçın Toker, Toker Yayınları İstanbul, 1995.

${ }^{78}$ Ayrıntılı bilgi için bkz. Tanıl Bora. "Milli Tarih ve Devlet Mitosu". Birikim Dergisi. Sayı:105-106. 1998. 
Gumilev, L. N, Etnogenez Halkların Şekillenişi, Yükseliş ve Düşüşleri, çev. Ahsen Batur, Selenge Yayınları. İstanbul, 2004.

Günay, Üren ve Güngör Harun, Başlangıçtan Günümüze Türklerin Dini Tarihi, Ocak Yayınları, Ankara, 1997.

Gündüz, Şinasi, “Kutsal Hakkında Konuşmak: Dinsel Söylemde Mitos” Milel ve Nihal Dergisi, cilt:6, sayı:1, 2009.

İbn Haldun, Devlet, İlke Yayınları, İstanbul, 2013.

Karakaş, Selim, "Türklerin Orijinal Dinleri Meselesi" Gaziantep University Journal of Social Sciences, cilt:13, sayı:2, 2014.

Okur, Mehmet Akif, “Büyük Kimliğin İzinde: Genişleme Çağları Ergenekonlar ve Türklük" , Orta Asya'da İslam Temsilden Fobiye, editör, Muhammet Savaş Kafkasyalı, cilt:1, Ahmet Yesevi Ünv. Yayınları, Ankara-Türkistan, 2012.

Okur, Mehmet Naim, Türk Devletlerinde Yöneten -Yönetilen İlişkisi ve İktidarın Meşruiyetinin Temelleri, Büyük Hun Imparatorluğu'ndan Tanzimat Fermanı'na Kadar, Selçuk Üniversitesi, Sosyal Bilimler Enstitüsü, Yayınlanmamış Yüksek Lisans Tezi, Konya, 2007.

Rousseau, Jean Jacques, Toplum Sözleşmesi, Qraf Yayınları, İstanbul, 2013.

Şeriati, Ali, Medeniyet Tarihi I, çev. İbrahim Keskin, Fecir Yayınları, Ankara, 1998.

Şimşek, Osman, "Devlet Kavramının Gelişimi ve Küreselleşmedeki Anlamı" Kaynak Site: http://www.kamu-is.org.tr/pdf/5413.pdf. Erişim Tarihi: 04.06.2017

Timurluoğlu, Vecihi, “Mitolojide Devlet Bilgisi” Memleket Siyaset Yönetim Dergisi, sayı:1, 2006.

Turan, Metin, Türk Destanları, Açıköğretim Fakültesi Yayınları, Kaynak Site:https://fevzioz.files.wordpress.com/2014/01/acc4b1klama-destan2.pdf. Erişim Tarihi:10.06.2017.

Wintson, Robert, Tanrının Öyküsü Tanrı mı Insanı, Insan mı Tanrı'yı Yarattı, Say Yayınları, İstanbul, 2005.

Yuvalı, Abdülkadir, “Türk Devlet Felsefesi”, Sakarya Üniversitesi Fen Edebiyat Fakültesi Dergisi, sayı:1, 2008 